Magazine of Concrete Research Volume 68 Issue 1

Punching shear strength of RC flat slabs at interior connections to columns Bompa and Onet

\title{
Punching shear strength of RC flat slabs at interior connections to columns
}

\section{Dan V. Bompa}

Post-doctoral Research Associate, Imperial College London, London, UK
Traian Onet

Professor, Technical University of Cluj-Napoca, Cluj-Napoca, Romania

A method to evaluate the punching shear strength of reinforced concrete (RC) flat slabs without shear reinforcement at the connection to interior columns is proposed. The method is based on the assumption that the punching shear strength is controlled by the inclination of a unique punching shear crack that produces a conical failure surface. The inclination angle of the crack is variable. It follows that the location of the critical section is not established in advance, but changes with crack angle. Its location depends on the reinforcement ratio, material strengths and effective depth. According to the proposed method, the punching shear strength is a function of the inclination angle of the governing crack that controls the amount of shear carried by the compression zone and the flexural reinforcement crossing the potential punching cone by accounting for its slenderness and concrete size effect. The method describes the behaviour observed in tests and numerical and analytical investigations. The novel premise that the punching shear strength of flat slabs at connections to interior columns is controlled by the inclination of the failure surface shows remarkable agreement with the results of 209 tests on isolated specimens reported in the literature. This paper also assesses the adequacy of strength predictions obtained using the proposed method and the methods adopted in the codified provisions.

\section{Notation}

$A_{\mathrm{pc}} \quad$ area of crack interface (punching cone)

$b_{0} \quad$ control perimeter

$b_{\mathrm{c}} \quad$ column dimension

$d \quad$ effective depth

$d_{i} \quad$ damage parameter

$d_{\mathrm{g}} \quad$ aggregate size

$E_{\mathrm{c}} \quad$ concrete modulus of elasticity

$E_{\mathrm{s}} \quad$ steel modulus of elasticity

$f_{\mathrm{c}} \quad$ concrete compressive strength on cylinder tests

$f_{\text {ct }} \quad$ concrete tensile strength

$f_{\mathrm{v}} \quad$ shear strength of plain concrete

$f_{\mathrm{y}} \quad$ yield strength of flexural reinforcement

$G_{\mathrm{f}} \quad$ fracture energy $\left(G_{\mathrm{f}}=73\left(f_{\mathrm{c}}\right)^{0 \cdot 18}\right)$

$h_{\mathrm{s}} \quad$ slab thickness

$K_{\mathrm{c}} \quad$ shape of deviatoric plane

$l_{0} \quad$ length of punching crack pattern at top face of slab at centroid of flexural reinforcement predicted by Equation 9

$l_{\text {ch }} \quad$ fractal parameter of concrete $\left(l_{\mathrm{ch}}=G_{\mathrm{f}} E_{\mathrm{c}} /\left(2 f_{\mathrm{ct}}\right)\right)$

$l_{\mathrm{s}} \quad$ span

$p, q \quad$ stress invariants, load

$m \quad$ bending moments

$r_{0} \quad$ radius of punching crack at top face of slab

$r_{\mathrm{s}} \quad$ slab radius

$V \quad$ punching shear strength

$V_{\text {flex }} \quad$ flexural strength

$\beta \quad$ internal friction angle

\author{
strain \\ eccentricity of plastic surface \\ crack inclination \\ slenderness of punching cone \\ size effect \\ flexural reinforcement ratio \\ stress \\ tangential stress \\ dilation angle of material \\ rotation \\ mechanical reinforcement ratio
}

\section{Introduction}

Situations in which the use of flat-slab structural systems has proved to be effective are countless. The solution has attracted much attention due to its simple and advantageous construction process. The design of such systems is typically governed by localised effects such as large midspan deflections in service or punching shear at ultimate. Uncertainties mainly exist regarding the behaviour of the connection region between the slab and the column. At interior columns, investigated here as isolated slab regions, the behaviour is potentially governed by punching shear even under sole gravity loading.

In three-dimensional (3D) reinforced concrete (RC) elements such as suspended slabs or footings, the behaviour in the connection region to the column is characterised by the 
development of flexural cracks at incipient loading stages (Figures 1(a) and 2(c)). At ultimate state they may govern, leading to a potential yielding of the longitudinal reinforcement (typical case for low amounts, see Figure 3(c) (Hallgren, 1996)). When flexural failure is not governing, but stresses in reinforcement bars are close to the yield stresses, flexural cracks propagate into shear cracks, leading to a failure mode defined as flexural punching (fib, 2001).

In the case of high reinforcement ratios, a slab will show stiffer behaviour, characterised by low stresses in the reinforcement and high stresses in the inclined concrete compression stress field that develops in the vicinity of the column (Figure 2(c)). A brittle failure, called punching shear, occurs when the inclined compression zone is unable to sustain any load increment (e.g. test HSC0 in Figure 3(a) (Hallgren, 1996)). Punching shear failure is described as the development of a diagonal crack of variable inclination starting from the face of the column (in the compression side of the slab) and ending at the tension face of the slab, resulting in the dislocation of a conical body from the concrete slab (Regan, 1986).

In concrete members, shear is typically carried through cracked interfaces by frictional resistance of the aggregates against crack slip and growth (Walraven and Reinhardt, 1981), shearing of the dowel bar (Dei Poli et al., 1987, 1992; Ince et al., 2007; Paulay and Loeber, 1974; Taylor, 1970),

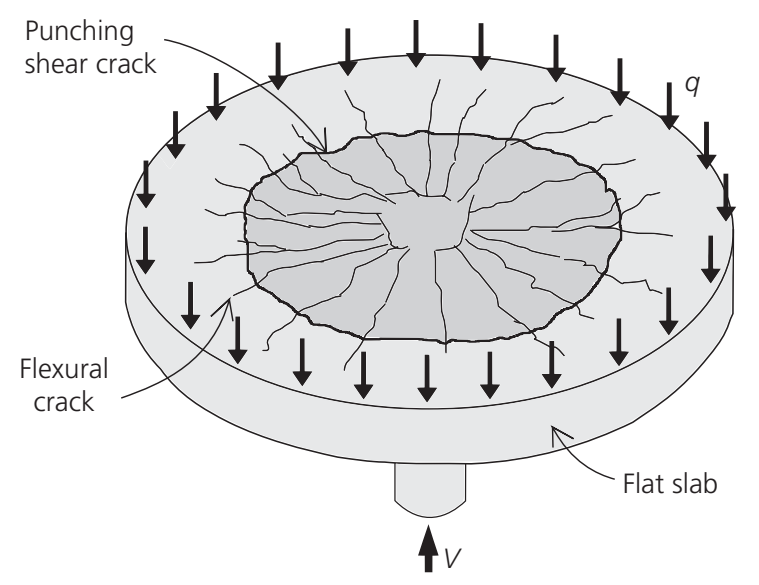

(a)

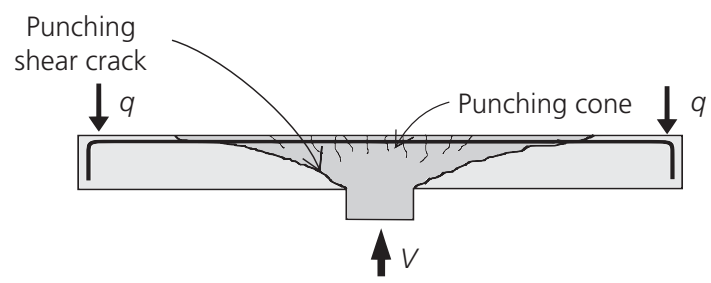

(b)

Figure 1. Isolated interior flat-slab-column region and typical punching shear failure surface: (a) isometric view; (b) section

$$
\text { Crack interface }
$$

(a)

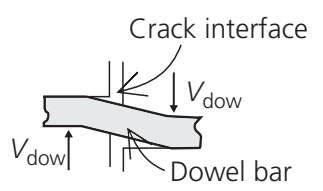

(b)

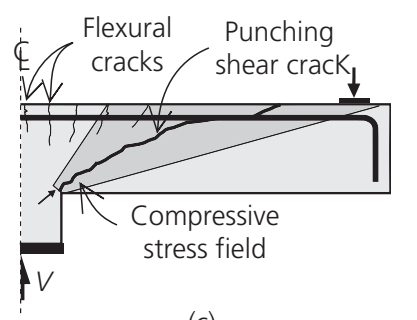

(c)
Figure 2. (a) Aggregate interlock. (b) Dowel action. (c) Compression field

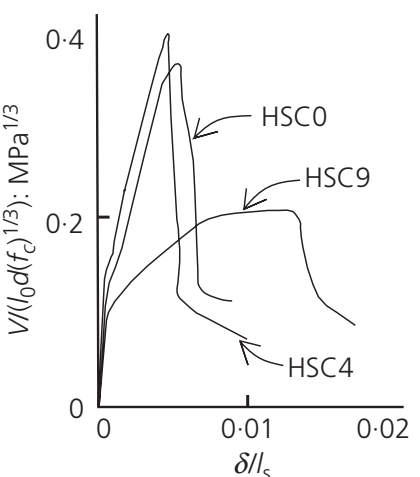

(a)

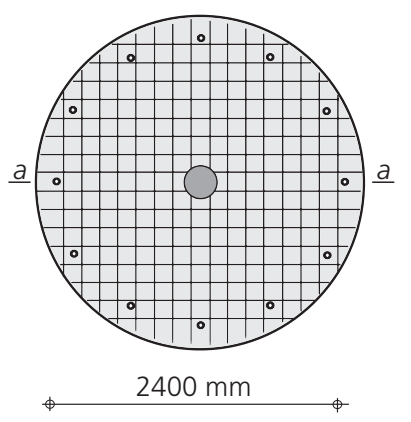

(b)

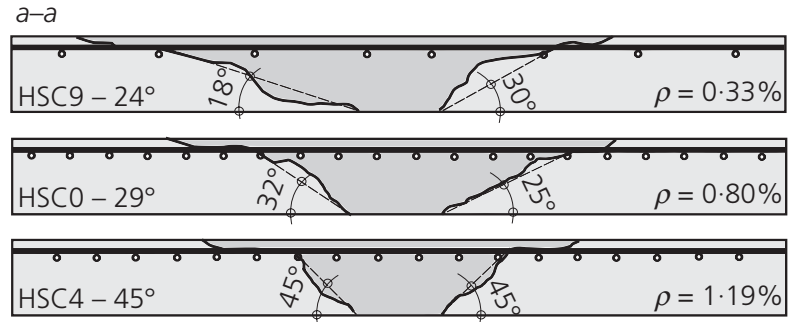

(c)

Figure 3. Tests (HSCO, HSC4 and HSC9) carried out by Hallgren (1996): (a) structural response; (b) in-plane geometrical configuration; (c) sectional views as a result of saw cuts

transfer through the concrete compression zone (Chana, 1987) and transfer of residual stresses through the crack tip (see Figures 2(a) and 2(b)). The inclination of the punching shear crack is governed by the stress distribution in the connection region. Its punching shear strength is governed by the amount of shear carried through the cracked interface. The inclination of the crack and the amount of shear carried through it are dependent on the geometry of the member (depth, slenderness, column dimension to slab thickness) and the characteristics of the structural parameters (material strengths, aggregate distribution and dimension, reinforcement layout etc.). 
The magnitude of shear transferred by aggregate interlock is dependent on the inclination of the cracked interface: the flatter the inclination angle, the higher the interlocking surface and, consequently, in the case of slabs, the higher the amount of shear transferred by this action. On the other hand, the length of the intersection line between the punching cone and the reinforcement plane is also controlled by the inclination of the governing punching shear crack. As the crack inclination angle reduces, the number of bars subjected to dowel action increases. Regan and Braestrup (1985) reported that 34\% of the ultimate punching shear strength is attributed to this mechanism. Hence, the inclination of the governing punching shear crack is a key parameter that controls the punching shear strength of slabs.

Although intense research has been done in recent decades in this field (e.g. Bazant and Cao, 1987; Broms, 1990; Elstner and Hognestad, 1956; Hallgren, 1996; Hegger et al., 2009; Kinnunen and Nylander, 1960; Muttoni, 2008; Regan, 1986), punching shear is still a polemic topic and methods to improve the phenomenological understanding and advancement in the state of the art are needed. This paper proposes a novel method to assess the punching shear strength of flat slabs without transverse reinforcement at the connection to interior columns. The method is based on the assumption that the key parameter that controls the punching shear strength is the inclination of the punching shear crack, which increases linearly with reinforcement ratio and effective depth. The location of the critical section varies with slab geometry and material characteristics. In the case of steep crack angles, the critical section lies closer to the column whereas, for flat crack angles, the critical section is found further from the column.

The component-based method proposed here accounts for the contribution of the following variables: concrete compression zone, interlocking of the aggregates, the dowel action of the reinforcement bars, the shape and slenderness of the punching cone and concrete-specific size effect. The magnitude of each variable is controlled by the inclination of the punching shear crack. The method is based on information obtained in tests (Bompa and Oneț, 2011; Gosav et al., 2013) and numerical parametric and analytical studies. Compared with existing design guidelines it offers better control since it accounts for a higher variety of structural parameters. The method is applicable to the evaluation of the punching shear strength of flat slabs without shear reinforcement connected to interior columns with circular or rectangular cross-sections. It shows remarkable agreement with the results of a series of 209 tests on isolated specimens reported in the literature (suspended slabs and footings) and can be successfully applied to the design of continuous flat slabs since the beneficial effect of compressive membrane action, disregarded here, may increase the punching shear strength at ultimate state. The paper also assesses the adequacy of the method in comparison with the predictions of current codified approaches.

\section{Parameters governing punching shear strength}

Figure 4(a) plots the relationship between the normalised punching shear strength and the concrete strength of specimens from the available database $\left(V I l_{0} d\left(f_{\mathrm{c}}\right)^{1 / 3}\right.$, where $V$ is the reported punching shear strength in tests). Hallgren (1996) reported that an increase in concrete strength $\left(f_{\mathrm{c}}\right)$ from $25 \mathrm{MPa}$ to $90 \mathrm{MPa}$ for a flexural reinforcement ratio of $0 \cdot 8 \%$ brought a significant increase (50-60\%) in punching shear strength whereas, for a low reinforcement ratio $(\rho=0.3 \%)$ the corresponding increase was $20 \%$ (Figure 3 ). The use of highstrength concrete with a low reinforcement ratio resulted in bending controlled failure (flexural punching), whereas the use of normal-strength concrete for the same $\rho$ resulted in brittle punching without reaching the flexural strength (Hallgren, 1996). Inacio et al. (2013) showed that an increase in concrete strength (from $35 \mathrm{MPa}$ to $125 \mathrm{MPa}$ ) resulted in the development of higher brittleness.

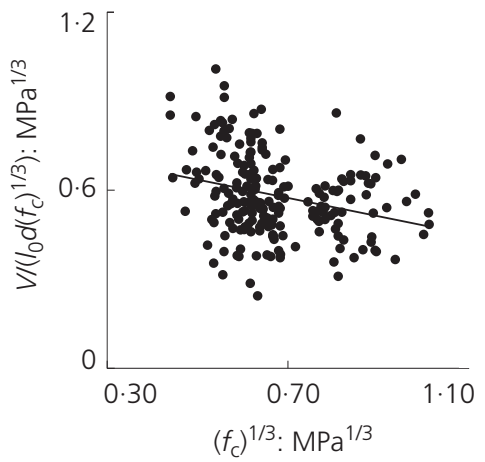

(a)

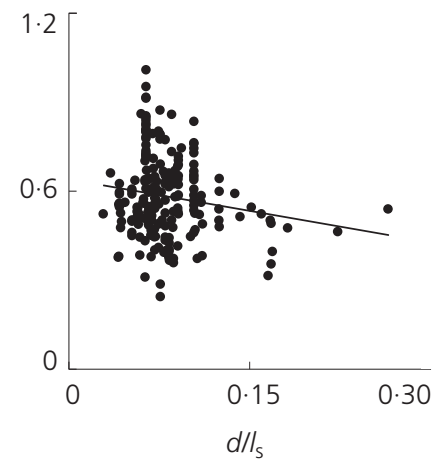

(b)

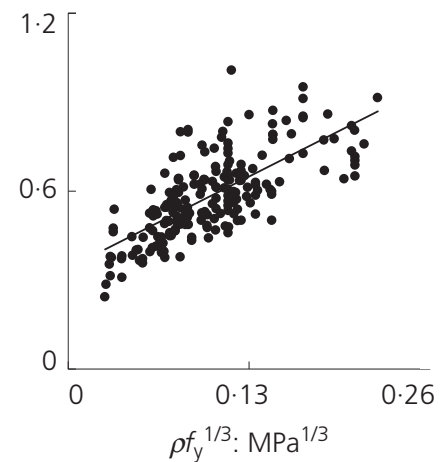

(c)

Figure 4. Analytical study on key parameters on reported test

database for the influence of (a) concrete strength, (b) slab

slenderness and (c) reinforcement ratio 
One of the key parameters in increasing the punching shear strength is the thickness of the slab. The modification of thickness from $200 \mathrm{~mm}$ to $260 \mathrm{~mm}$ for a high reinforcement ratio $(\rho=1.25 \%)$, accounting for low concrete strength $\left(f_{\mathrm{c}}<20 \mathrm{MPa}\right)$ and variable slenderness, resulted in a $28 \%$ decrease in nominal strength (Gosav et al., 2013). Slenderness was likewise reported to be key parameter in the behaviour of flat slabs (Moe, 1961). According to the test database, a slender specimen has a lower nominal punching strength, whereas a more robust one shows an increase in nominal punching strength (Figure 4(b)).

Maintaining a constant aspect ratio, Guandalini et al. (2009) tested a series of full-scale specimens with a low amount of bending reinforcement $(\rho=0 \cdot 33 \%)$ and varying thickness of $250-500 \mathrm{~mm}$. The nominal capacity of the $500 \mathrm{~mm}$ thick specimen was $17 \%$ smaller than that of the $250 \mathrm{~mm}$ thick specimen. It can be said that an increase in thickness has a greater influence for specimens with moderate and high flexural reinforcement ratios. In addition, an increase in thickness has a comparatively lower effect on the nominal punching capacity for thin slabs $\left(h_{\mathrm{s}}<200 \mathrm{~mm}\right)$, but a considerable effect for thick ones $\left(h_{\mathrm{s}}>200 \mathrm{~mm}\right)$. The size effect, characteristic for brittle materials such as concrete, was previously addressed for flat slabs by Bazant and Cao (1987), Broms (1990) and Menetrey (2002).

Figure 4(c) shows the relationship between the reinforcement ratio and ultimate strength on a series of tests gathered from the database (Table 1). For low reinforcement ratios, bendingcontrolled behaviour develops, leading to potential flexural failures. The behaviour of slabs with low reinforcement is characterised by flexibility, higher deflections and flatter governing punching shear cracks. On the other hand, slabs with high reinforcement ratios develop a stiff behaviour characterised by small deflections and steep diagonal cracks (Figures 3(a) and 3(c)). On the same topic, Regan (1986) reported that, in the case of slabs when the failure surface crosses the reinforcement, the nominal stress is proportional to the cube root of the ratio of reinforcement, which is faithfully captured in Figure 4(c).

\section{Numerical investigation}

This section describes numerical investigations carried out using the finite-element package Abaqus 6.10 (DSS, 2010) to obtain insight into the force transfer paths within a concrete body. The objective of the investigation was to see the effect of a change in slab thickness on the angle of the compression stress field. The concrete damaged plasticity model (CDP) is used to represent the triaxial behaviour of concrete. The CDP is an isotropic scalar damage model that uses a potential yield surface in the effective stress space $(\bar{\sigma})$ derived from a combined Drucker-Prager and Rankine representation (Equation 1). The plastic volume expansion is not proportional to the increase in stresses (i.e. non-associative flow rule (Equation 2)).
The plastic yield surface is dependent on several parameters, such as dilation angle of the material $\phi$, eccentricity of the plastic surface $\epsilon$, material strengths and effective stresses (Equation 3). The constitutive model requires a set of material functions: uniaxial stress-strain relationships and related scalar damage ratios (Equation 4 where $i$ represents compression or tension). A simple bi-linear elasto-plastic relationship for steel is used.

\section{1. $G=\left[\left(\in f_{\mathrm{ct}} \tan \phi\right)^{2}+\bar{q}^{2}\right]^{1 / 2}-\bar{p} \tan \phi$}

3. $\bar{\sigma}_{i}=\frac{\sigma_{i}}{1-d_{i}}$

4. $\sigma_{i}=\left(1-d_{i}\right) E_{\mathrm{c}}\left(\varepsilon_{i}-\tilde{\varepsilon}_{i}^{\mathrm{pl}}\right)$

\section{Validation model}

In order to set the material parameters, the numerical model was validated for specimen DB5 tested previously by the authors (Bompa and Oneț, 2011). The flat slab depicted in Figure 5 measured $1.5 \mathrm{~m}$ by $1.5 \mathrm{~m}$, was $170 \mathrm{~mm}$ thick and had no shear reinforcement. The connection comprised a stub column of $300 \mathrm{~mm}$ by $300 \mathrm{~mm}$ cross-section and $600 \mathrm{~mm}$ height. The specimen was tested upside down with load introduction directly to the column through a $3 \mathrm{D}$ pinned joint. The top and bottom reinforcement consisted of $10 \mathrm{~mm}$ ribbed bars with a yield strength of $583 \mathrm{MPa}$. The mean concrete compressive cube strength determined by means of material tests was $f_{\text {c,cube }}=43.9 \mathrm{MPa}$. The cylinder compressive $(35.1 \mathrm{MPa})$ strength was computed by accounting a correspondence factor between cylinder and cube strength of 0.8 and the concrete elastic modulus was computed according to Model Code 2010 (MC2010) provisions (fib, 2012). The tensile strength determined by means of indirect splitting tests was $2 \cdot 12 \mathrm{MPa}$. The clear concrete cover was $15 \mathrm{~mm}$ on both top and bottom faces.

Three-dimensional models for RC flat slabs adopt eight-noded brick elements for concrete members and load transfer plates in conjunction with 3D wire elements for the reinforcement. The slab was linearly restrained through reaction plates with the corners free to lift. The moment span on both orthogonal directions was $1450 \mathrm{~mm}$. A mesh sensitivity study indicated a notable influence on the simulated behaviour. Good agreement 


\begin{tabular}{|c|c|c|c|c|c|c|c|c|c|c|c|c|c|c|c|}
\hline \multirow[b]{3}{*}{ Author(s) } & \multirow{3}{*}{ 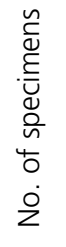 } & \multirow{3}{*}{$\begin{array}{l}d_{\min }-d_{\max }: \\
\mathrm{mm}\end{array}$} & \multirow{3}{*}{$\begin{array}{c}\rho_{\min }-\rho_{\max }: \\
\%\end{array}$} & \multirow{3}{*}{$\begin{array}{l}f_{c, \text { min }}-f_{c, \text { max }}: \\
M P a\end{array}$} & \multirow{3}{*}{$\begin{array}{l}f_{y, \min }-f_{y, \max }: \\
\mathrm{MPa}\end{array}$} & \multicolumn{10}{|c|}{$V_{\text {test }} / V_{\text {calc }}$} \\
\hline & & & & & & \multicolumn{2}{|c|}{ Equation 13} & \multicolumn{2}{|c|}{ Equation 14} & \multicolumn{2}{|c|}{$\begin{array}{l}\text { Eurocode } 2 \\
\text { (Equation 17a) }\end{array}$} & \multicolumn{2}{|c|}{$\begin{array}{l}\text { ACl 318-14 } \\
\text { (Equation 18) }\end{array}$} & \multicolumn{2}{|c|}{$\begin{array}{r}\text { MC2010 (LoA2) } \\
(\text { (Equation 19a) }\end{array}$} \\
\hline & & & & & & Average & $\mathrm{CoV}$ & Average & $\mathrm{CoV}$ & Average & $\mathrm{CoV}$ & Average & $\mathrm{CoV}$ & Average & $\mathrm{Cov}$ \\
\hline Al-Yousif and Regan (2003) & 2 & 80 & 0.9 & $27 \cdot 5-29 \cdot 0$ & 472 & $1 \cdot 16$ & 0.06 & $1 \cdot 28$ & 0.07 & 0.91 & $0 \cdot 12$ & $1 \cdot 06$ & $0 \cdot 12$ & 0.99 & $0 \cdot 20$ \\
\hline Base (fib, 2001) & 20 & 102-124 & $1 \cdot 0-1 \cdot 9$ & $13 \cdot 3-39 \cdot 9$ & 255-432 & 1.00 & $0 \cdot 16$ & 0.99 & 0.16 & 1.00 & $0 \cdot 15$ & 1.46 & $0 \cdot 18$ & 1.06 & $0 \cdot 21$ \\
\hline $\begin{array}{l}\text { Elstner and Hognestad } \\
\text { (1956) }\end{array}$ & 14 & 114-118 & $1 \cdot 2-3 \cdot 0$ & $10 \cdot 7-39 \cdot 9$ & 321-409 & 1.04 & $0 \cdot 11$ & 1.03 & 0.13 & 1.03 & 0.09 & 1.62 & 0.16 & $1 \cdot 16$ & $0 \cdot 14$ \\
\hline $\mathrm{EPFL}^{\mathrm{b}}$ & 12 & $96-456$ & $0 \cdot 3-1 \cdot 6$ & $25 \cdot 7-67 \cdot 0$ & $480-577$ & 0.96 & $0 \cdot 16$ & 0.92 & 0.16 & 1.02 & 0.08 & $1 \cdot 18$ & 0.25 & 1.09 & $0 \cdot 10$ \\
\hline $\mathrm{ETHZ}^{\mathrm{C}}$ & 3 & $143-294$ & $1 \cdot 2-1 \cdot 5$ & $27 \cdot 1-35 \cdot 5$ & $515-577$ & 0.95 & 0.09 & 0.92 & 0.11 & 1.03 & 0.05 & 1.47 & 0.09 & $1 \cdot 02$ & $0 \cdot 22$ \\
\hline $\begin{array}{l}\text { Bompa and Oneț (2011) and } \\
\text { Gosav et al. (2013) }\end{array}$ & 4 & $155-217$ & $0.5-1 \cdot 4$ & $17 \cdot 5-35 \cdot 11$ & 465-583 & 1.00 & $0 \cdot 17$ & 0.94 & 0.17 & 1.05 & $0 \cdot 14$ & $1 \cdot 29$ & 0.25 & 1.02 & 0.23 \\
\hline Hallgren (1996) & 6 & 194-201 & $0 \cdot 6-1 \cdot 2$ & $81 \cdot 4-103$ & $596-643$ & 0.93 & 0.04 & 0.89 & 0.06 & 0.99 & 0.04 & $1 \cdot 11$ & 0.06 & 0.93 & 0.06 \\
\hline Hegger et al. (2009) & 6 & 395 & 0.9 & $21 \cdot 1-36 \cdot 4$ & 552 & $1 \cdot 12$ & $0 \cdot 15$ & 0.95 & 0.15 & $1 \cdot 24$ & $0 \cdot 15$ & 1.54 & $0 \cdot 16$ & $1 \cdot 10$ & $0 \cdot 17$ \\
\hline Inacio et al. (2013) & 4 & 102-105 & $0.9-1.5$ & $35 \cdot 9-130$ & $493-523$ & $1 \cdot 04$ & 0.04 & 1.07 & 0.04 & 0.89 & 0.03 & 0.99 & 0.11 & 0.85 & 0.05 \\
\hline $\begin{array}{l}\text { Kinnunen and Nylander } \\
\text { (1960) }\end{array}$ & 10 & $117-128$ & $0 \cdot 8-2 \cdot 1$ & $24 \cdot 3-31 \cdot 0$ & $436-461$ & 0.96 & $0 \cdot 10$ & 0.95 & 0.12 & $1 \cdot 00$ & 0.09 & 1.59 & 0.15 & $1 \cdot 01$ & $0 \cdot 12$ \\
\hline Mongi (1990) & 16 & 78 & $1 \cdot 5-2 \cdot 9$ & 4 & $380-480$ & $1 \cdot 01$ & $0 \cdot 14$ & 1.03 & 0.14 & 0.99 & $0 \cdot 14$ & 1.91 & 0.17 & $1 \cdot 10$ & $0 \cdot 18$ \\
\hline $\begin{array}{l}\text { Ladner (1998) and Ladner } \\
\text { et al. (1977) }\end{array}$ & 7 & $80-240$ & $1 \cdot 2-1 \cdot 8$ & $27 \cdot 6-36 \cdot 7$ & 528-550 & $1 \cdot 13$ & $0 \cdot 13$ & $1 \cdot 11$ & 0.16 & 1.06 & $0 \cdot 14$ & 1.59 & 0.11 & 1.09 & 0.11 \\
\hline $\begin{array}{l}\text { Marzouk and Hussein (1991) } \\
\text { and Rizk et al. (2011) }\end{array}$ & 19 & $90-313$ & $0.5-2$ & $40-80$ & $400-4 \mathrm{~S}$ & 1.02 & $0 \cdot 12$ & 1.00 & 0.11 & 0.99 & $0 \cdot 10$ & $1 \cdot 19$ & 0.26 & 0.95 & 19 \\
\hline McGill ${ }^{a}$ & 11 & $100-300$ & $0.8-1.9$ & $0 \cdot 1-67 \cdot 1$ & $434-488$ & 0.99 & $0 \cdot 11$ & 1.00 & 0.13 & 0.95 & $0 \cdot 15$ & $1 \cdot 19$ & 0.11 & 0.91 & $0 \cdot 10$ \\
\hline Moe (1961) & 14 & 114 & $1 \cdot 1-2 \cdot 6$ & $19 \cdot 5-33 \cdot 4$ & $328-483$ & $1 \cdot 14$ & $0 \cdot 16$ & 1.09 & 0.17 & $1 \cdot 15$ & $0 \cdot 17$ & 1.91 & $0 \cdot 11$ & 1.45 & $0 \cdot 19$ \\
\hline Oliveira e & 10 & 106-109 & 1.1 & $54 \cdot 0-67 \cdot 0$ & 479 & 10 & 0.05 & $1 \cdot 10$ & 0.07 & 0.90 & 0.06 & 1.04 & 0.17 & 0.92 & $0 \cdot 13$ \\
\hline Ramadane (1996) & 11 & 98-102 & $0 \cdot 6-1 \cdot 3$ & $26 \cdot 5-97 \cdot 2$ & $550-650$ & $1 \cdot 01$ & $0 \cdot 13$ & 0.99 & 0.13 & 1.05 & $0 \cdot 10$ & 1.66 & $0 \cdot 10$ & $1 \cdot 16$ & $0 \cdot 11$ \\
\hline Regan (1986) & 11 & $64-200$ & $0 \cdot 8-1 \cdot 2$ & $21 \cdot 6-35 \cdot 7$ & $480-530$ & $1 \cdot 02$ & 0.07 & 1.05 & $0 \cdot 10$ & 0.97 & 0.05 & $1 \cdot 27$ & 0.09 & $1 \cdot 23$ & $0 \cdot 19$ \\
\hline Tomaszewicz (1 & 13 & $88-275$ & $1 \cdot 5-2 \cdot 6$ & $64 \cdot 1-118$ & 500 & $1 \cdot 02$ & 0.07 & 0.92 & 0.07 & 1.05 & 0.08 & 1.47 & 0.08 & $1 \cdot 10$ & $0 \cdot 10$ \\
\hline Urban et & 3 & $218-318$ & 0.4 & 32.5 & $544-580$ & $1 \cdot 17$ & 0.09 & $1 \cdot 10$ & 0.06 & $1 \cdot 61$ & $0 \cdot 10$ & 1.83 & 0.11 & $1 \cdot 61$ & $0 \cdot 13$ \\
\hline \multirow[t]{2}{*}{ Various $^{\mathrm{d}}$} & 13 & $100-260$ & $0 \cdot 6-2 \cdot 2$ & $21 \cdot 9-56 \cdot 1$ & $420-481$ & 0.92 & 0.09 & 0.91 & $0 \cdot 10$ & 0.98 & $0 \cdot 11$ & $1 \cdot 22$ & 0.29 & 0.94 & $0 \cdot 22$ \\
\hline & 209 & & & & & 1.02 & $0 \cdot 13$ & 1.00 & 0.14 & $1 \cdot 02$ & $0 \cdot 15$ & $1 \cdot 44$ & 0.25 & 1.08 & 0.21 \\
\hline
\end{tabular}

ahannoum (1998), McHarg (1997) and Kevin (2000)

'Guandalini et al. (2009), Guidotti (2010), Krueger (1999) and Sagaseta et al. (2011)

'Heinzmann (2012) and Pralong (1982)

'Beutel (2002), Birkle and Digler (2008), Broms (1990), Caldentey et al. (2013), Moreno and Sarment (2013), Schaefers (1984), Swamy and Ali (1982) and Wörle (2014)

Cov: coefficient of variance

Table 1. Database of punching shear tests 
between the test and numerical results regarding both stiffness and stress values was found for a mesh size of $\approx 19 \mathrm{~mm}$, resulting in nine layers of mesh for the slab thickness. The arc length method was used as the integration procedure. In the case of cohesive-brittle materials such as concrete, the internal friction angle $\beta$ and dilation angle $\phi$ play a notable role in obtaining a reliable numerical response. A commonly agreed range of values for $\phi$ is $20-40^{\circ}$. It was observed that the best response was received for a dilation angle of $40^{\circ}$. The other constitutive parameters were also varied, resulting in shape of the deviatoric plane $K_{\mathrm{c}}=2 / 3$ and eccentricity of the plastic surface $\epsilon=0 \cdot 1$.

Figure 5(a) plots the numerical response against the response recorded in the test. The ultimate strength in the numerical simulation was reached due to a localised crushing failure in the stress field formed in the slab near the column region (Figure 5 (d)). The first yield of the flexural reinforcement was recorded at $440 \mathrm{kN}$, which was similar to the value obtained by means of analytical modelling (Muttoni, 2008). The tension damage map shows a flexural-controlled behaviour at early loading stages with the concentration of damage following typical yield line patterns. At failure, the internal damage pattern is represented by a conical shape (Figure 5(c)), resembling the test recorded crack pattern at the top face of the slab (Figure 5(b)).

\section{Parametric investigation}

In order to assess the elastic stress fields that develop within interior slab to column connections, a series of eight flat-slab

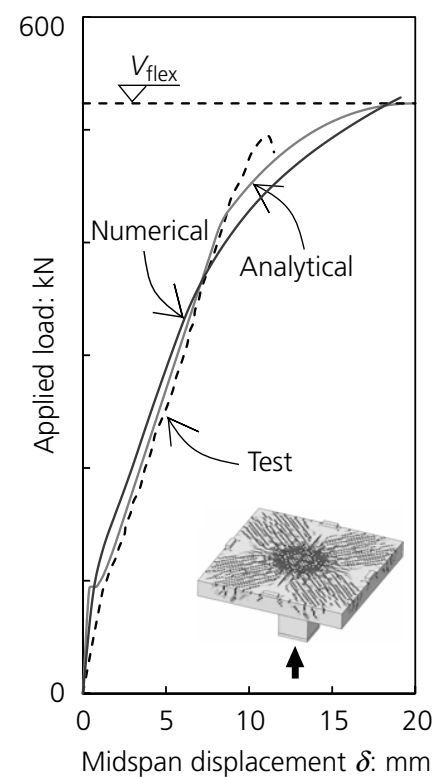

(a)

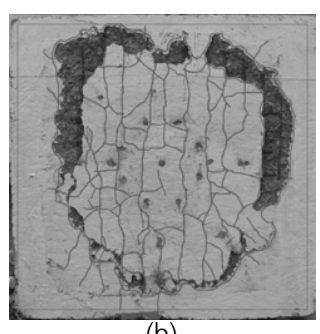

(b)

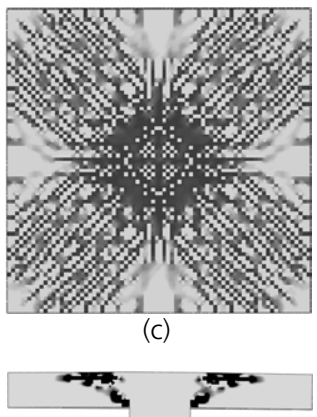

(d)
Figure 5. (a) Numerical calibration of test specimen DB5; loaddisplacement response. (b) Crack pattern on top face of specimen. (c) Tension damage in numerical model. (d) Compression damage in slab section column connections was examined by varying the slab thickness. The average effective depth of 209 specimens from the literature (Table 1) is $146 \mathrm{~mm}$. Specimen DB5 was used as a reference to validate the numerical model since its effective depth $\left(d_{\mathrm{DB} 5}=145 \mathrm{~mm}\right)$ was nearly identical to the average value in the database. In the parametric study, the reinforcement ratio, steel yield strength and concrete strength were maintained constant, whereas the thickness was varied (Figure 6). The moment span was maintained constant for all models. Figure 6(b) show the relationship between the studied parameters against the ultimate strength resulting from the Ottosen yield criterion over the numerical response (Ottosen, 1980). The thickness variation from $150 \mathrm{~mm}$ to $500 \mathrm{~mm}$ showed a proportional increase regarding the inclination of compression stress field (Figure 6(a)) and a decrease in the normalised strength with the increase of slenderness (Figure 6(b)). Due to limited thickness, in thin slabs, the inclination of the compression field is $31^{\circ}$, whereas for thicker slabs it tends to follow a $45^{\circ}$ path. For thick slabs, there is less geometrical constraint in the development of the compression stress field. Therefore it is natural to have steeper inclinations.

\section{Ultimate punching shear strength}

A novel method to assess the punching shear strength of flat slabs at the connection to interior columns is proposed here. The method was developed from the assumptions that the shear is carried by a 3D strut formed around the column and the concrete characteristic shear transfer actions. The key parameter that controls the punching shear strength is the inclination of the punching shear crack, which increases linearly with the reinforcement ratio and effective depth. The location of the critical section varies with slab geometry and material characteristics. The method disregards the beneficial effect of compressive membrane action and hence it offers a safe estimate. The inclination of the punching shear crack is governed by the stress distribution in the connection region. The punching shear strength, evaluated at the conical failure surface, is governed by the amount of shear carried through the cracked interface. The crack inclination angle and the amount of shear carried through the failure surface are dependent on the geometry of the member (depth, slenderness, column dimension to slab thickness) and the characteristics of the structural key parameters (material strengths, aggregate distribution and dimension, reinforcement layout etc.).

The transfer of residual stresses through the fracture process zone is not accounted for. The method proposed here was validated with a series of isolated specimens tested in various support and load conditions and is limited to interior connections without shear reinforcement.

Considering a variable inclination of the punching shear crack, the proposed method offers better control compared with existing design guidelines since it accounts for a higher variety of 


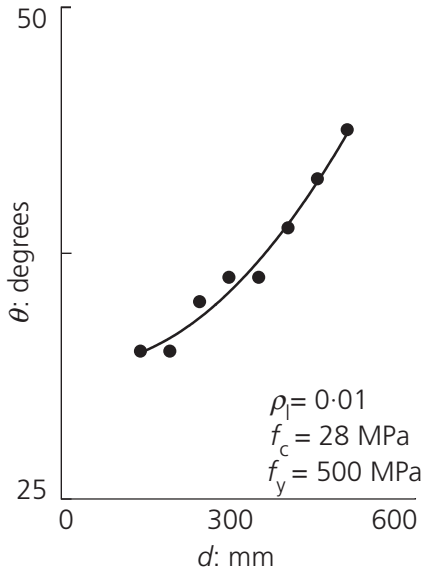

(a)

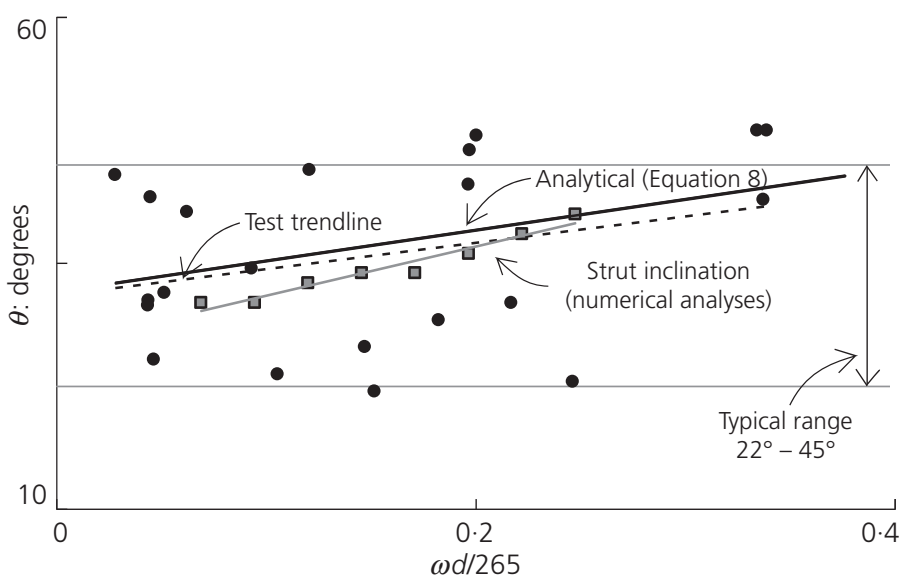

(c)

Figure 6. (a) Relationship between strut inclination and effective depth of the slab. (b) Normalised punching shear strength related to slab slenderness. (c) Relationship between crack inclination (reported in tests), strut inclination (by means of numerical

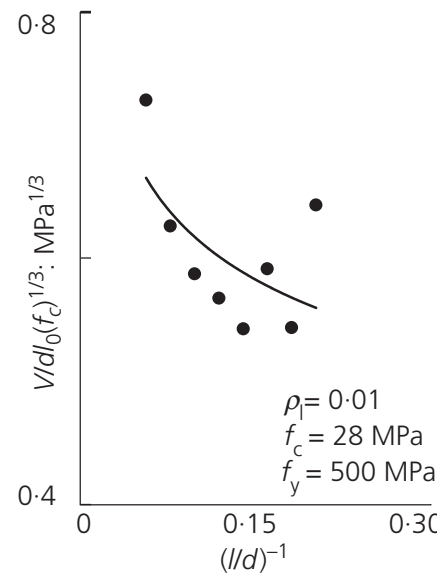

(b)
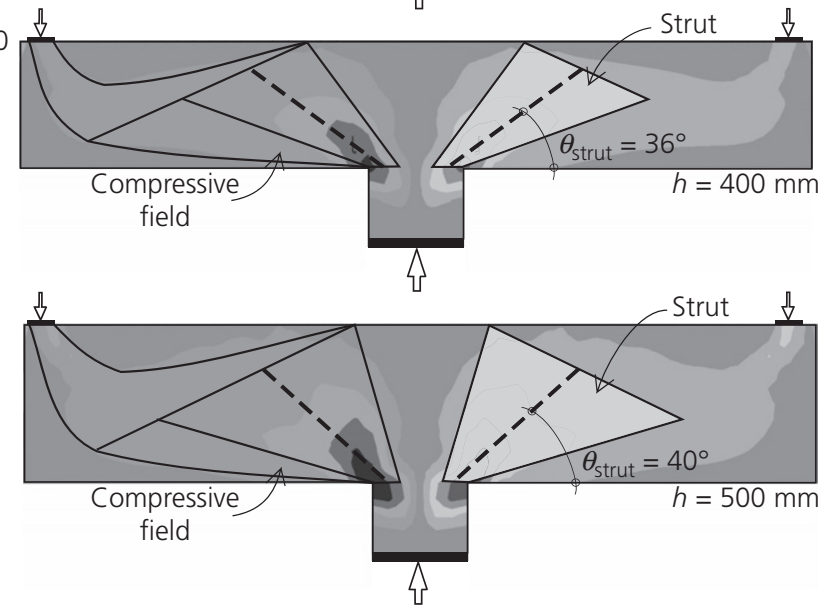

(d)
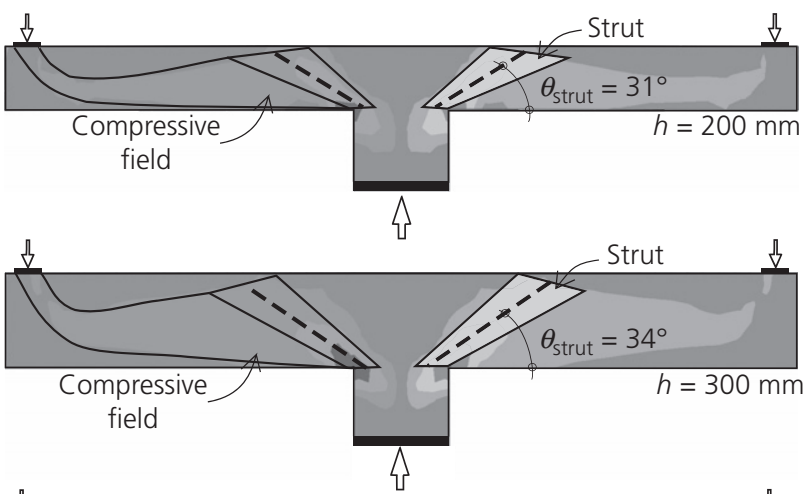

analyses) and analytical prediction (Equation 8). (d) Finite-element analysis plots and assumptions for strut inclination in relation to slab thickness.

structural parameters. The method is applicable to the assessment of the punching shear strength of flat slabs connected to interior columns with circular or rectangular cross-sections without shear reinforcement. The method proposed was validated with 209 tests on isolated specimens reported in the literature (suspended slabs and footings) (Al-Yousif and Regan, 2003; Bazant and Cao, 1987; Bernaert and Puech, 1966; Beutel, 2002; Birkle and Digler, 2008; Bompa and Oneț, 2011; Broms, 1990; Caldentey et al., 2013; Elstner and Hognestad, 1956; Ghannoum, 1998; Guandalini et al., 2009; Gosav et al., 2013; Guidotti, 2010; Hallgren, 1996; Hegger et al., 2009; Heinzmann et al., 2012; Inacio et al., 2013; Kevin, 2000; Kinnunen and Nylander, 1960; Krueger, 1999; Ladner, 1998; Ladner et al., 1977; Marzouk and Hussein, 1991; McHarg, 1997; Menetrey, 2002; Moe, 1961; Mongi, 1990; Moreno, 2013; Muttoni, 2008; Muttoni and Fernandez Ruiz, 2012; Oliveira et al., 2004; Pralong, 1982; Ramadane, 1996; Regan, 1986; Rizk et al., 2011; Sagaseta et al., 2011; Schaefers, 1984;
Swamy and Ali, 1982; Tomaszewicz, 1993; Urban et al., 2013; Wörle, 2014). The condensed results can be found in Table 1 and the extended data for calculation in the Appendix.

\section{Prediction method}

A prediction method was developed based on previous findings by means of numerical analyses, analytical investigations on the existing test database (Table 1) and test observations carried out by the authors (Bompa and Onet, 2011; Gosav et al., 2013). The method has, as its basis, the concept of variable inclination of the unique punching shear crack (Figure 7(a)). Considering that the angle of the crack is defined by the line that connects the root of the column to the intersection of the crack with the flexural reinforcement, the reported angles as a result of saw cuts through the slab on 21 tests vary from $20^{\circ}$ to $49^{\circ}$ (Beutel, 2002; Guandalini et al., 2009; Hallgren, 1996; Hegger et al., 2009; Heinzmann et al., 2012; Ladner, 1998; Pralong, 1982) (e.g. Figure 3(b)). In agreement 


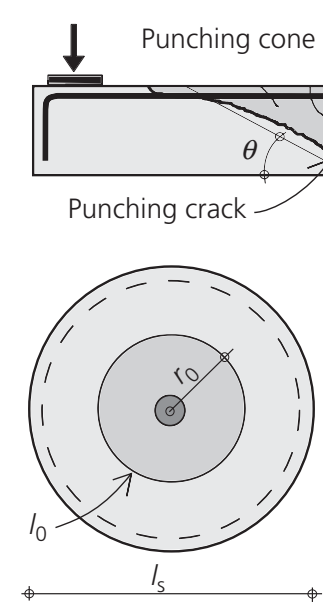

(b)

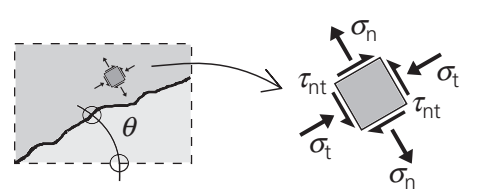

(d)

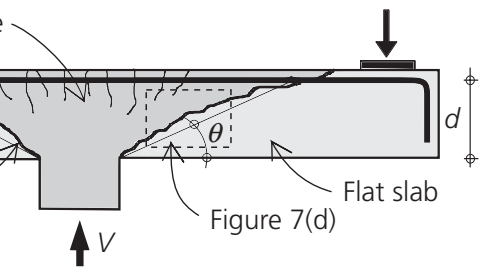

(a)

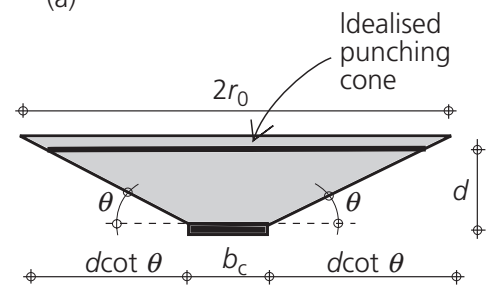

(c)

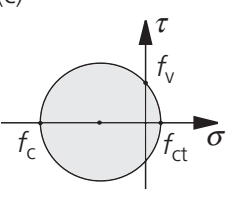

(e)
Figure 7. (a) Typical punching shear failure for flat slabs near column region. (b) In-plane dimensions of slab. (c) Dimensions of the punching cone. (d) State of stresses above the punching shear crack. (e) Mohr circle for concrete strengths

with the results in Figures 6(c) and 6(d), a correlation between the inclination of the compression stress field (numerical) and average crack inclination reported from tests was found (Equation 5). The predicted crack angle depends on the reinforcement ratio $\rho$, the effective depth $d$ and the material strength ratio $f_{\mathrm{y}} / f_{\mathrm{c}}$. The influence of slab thickness on crack inclination angle was calibrated against the average effective depth of the slabs with available reported saw cuts (i.e. $d_{\mathrm{avg}}=265 \mathrm{~mm}$ ).

5a. $\tan \theta=0.6+\omega\left(\frac{d}{265}\right)^{1 / 2}$

5b. $\omega=\rho f_{\mathrm{y}} / f_{\mathrm{c}}$

The punching shear crack formed at the centreline of the compression field, connecting the root of the column to the tension face of the slab, produces a conical body that dislocates from the slab (Figures 7(a) and 7(c)). The resulting punching cone is defined geometrically by the column dimension $b_{\mathrm{c}}$, bending effective depth $d$ and inclination angle of the crack $\theta$. Assuming that the frustum of the cone has a circular shape at both lower and upper bases, the perimeter of the punching shear crack at the centroid of the flexural reinforcement is given by $l_{0}$ (Equation 6 ). In the case of rectangular columns, its dimension can be estimated by considering a circular column with the same area $\left(b_{\mathrm{c}}=2 b_{\mathrm{c}, \mathrm{r}} \mathrm{r} \pi^{1 / 2}\right)$. For rectangular columns with a column dimension ratio different from one, the column dimension can be regarded as the square root of the product of the two dimensions $b_{\mathrm{c}, \mathrm{r}}=\left(b_{\mathrm{c}, 1} \times b_{\mathrm{c}, 2}\right)^{1 / 2}$. The root of the column and the circular line at the top face of the slab represents the boundary between two rigid bodies that separate at failure (i.e. punching cone and slab). The area of the failure surface is the slant of the frustum of the cone (Equation 7).

6. $l_{0}=\pi\left(b_{\mathrm{c}}+2 d \cot \theta\right)$

\section{7. $A_{\mathrm{pc}}=\pi d\left(b_{\mathrm{c}}+d \cot \theta\right) / \sin \theta$}

Significant shear is transferred from the slab to the column through the inclined compression stress field (Figure 2(c)). Accounting for the state of stress in Figure 7(d), the increase in strut stresses results in tension in the normal direction $\left(\sigma_{n}\right)$. Considering that concrete is a Coulomb material, the typical failure modes are sliding and separation (Nielsen, 1999). Prior to separation of the two bodies, concrete can withstand a stress equal to the tensile strength in the normal direction to the crack $\left(\sigma_{\mathrm{n}}=f_{\mathrm{ct}}\right)$. The shear strength $f_{\mathrm{v}}$ in the region can be predicted using the Mohr-Coulomb criterion (Figure 7(e), Equation 10)). However, the assumptions are valid for plain concrete. In the case of $\mathrm{RC}$, the typical behaviour is disturbed. The influence is accounted for by considering the cube root of $f_{\mathrm{v}}$. In conjunction with the slenderness of the punching cone $\lambda$ (Equation 9), the contribution of the interlocking aggregates and the transfer through the compressive zone are estimated by Equation 8 .

Equation 11 is an application of the findings reported by Ince et al. (2007) regarding the shear response of the embedded dowels in concrete, which relates the strength of the dowel to the reinforcement ratio $\rho$, its yield strength $f_{\mathrm{y}}$, concrete strength $f_{\mathrm{c}}$ and aggregate size $d_{\mathrm{g}}$ (size effect). In this paper, the size effect is accounted for by the factor $\xi$ (Equation 16), which is dependent on the effective depth and the fractal parameter of the concrete (characteristic length $l_{\mathrm{ch}}$ ). Equation 11 is modified from the original form by disregarding the size effect and integrating the influence of dowel bending over the critical section $\left(l_{0} d\right)$. By using the reinforcement ratio and a fraction of the yield strength of the flexural reinforcement, in its general form Equation 11 takes into account the influence of flexural strength on the punching shear strength.

The punching shear strength of a slab at interior columns is given by Equation 13. A condensed form of the proposed method is also available. Considering that the relationship between the cube root of the shear strength and the cube root of the concrete strength is given by the equality in Equation 12 and the ratio $A_{\mathrm{pc}} / l_{0}=1.25 d$ (on average, considering the 
available database) Equation 13 can be condensed into Equation 14.

8. $V_{1}=\lambda A_{\mathrm{pc}}\left(f_{\mathrm{v}}\right)^{1 / 3}$

9. $\lambda=d /\left(b_{\mathrm{c}}+2 d \cot \theta\right)$

10. $f_{\mathrm{v}}=\left(f_{\mathrm{c}} f_{\mathrm{ct}}\right)^{1 / 2}$

11. $V_{2}=\rho_{1}\left(f_{\mathrm{y}}\right)^{1 / 3}\left(f_{\mathrm{c}}\right)^{1 / 3} l_{0} d$

12. $\left(f_{\mathrm{v}}\right)^{1 / 3} \cong \frac{2}{3}\left(f_{\mathrm{c}}\right)^{1 / 3}$

13. $V_{\mathrm{R}}=\left(V_{1}+V_{2}\right) \xi$

14. $V_{\mathrm{R}}=2 \pi d\left(f_{\mathrm{c}}\right)^{1 / 3}\left[0.4 d+\rho_{l}\left(f_{\mathrm{y}}\right)^{1 / 3} r_{0}\right] \xi$

15. $r_{0}=d \cot \theta+b_{\mathrm{c}} / 2$

16. $\xi=0.75+\left(d / l_{\mathrm{ch}}\right)^{-0.2}$

\section{Validation of the method}

Figures $8(\mathrm{a})$ and $8(\mathrm{~b})$ respectively show the predictions of Equations 13 and 14 considering the data listed Table 1 . The ratio of reported strength to predicted strength $\left(V_{\text {test }} / V_{\text {calc }}\right)$ is plotted against the ratio of the reported strength and the specimen's flexural strength $\left(V_{\text {test }} / V_{\text {flex }}\right)$. The database consists of 209 tests presenting a wide range of mechanical and geometrical parameters (55 slabs with circular columns and 154 slabs with rectangular columns of which 141 were square). The test specimens had various structural parameters. The flexural reinforcement ratio $(\rho)$ varied between $0 \cdot 33 \%$ and $3 \cdot 00 \%$. The compressive concrete strength, obtained on cylinder specimens, was $10 \cdot 7-130 \cdot 1 \mathrm{MPa}$, whereas the yield strength of bending reinforcement varied from $255 \mathrm{MPa}$ to $720 \mathrm{MPa}$. The in-plane dimensions varied from $0.73 \mathrm{~m}$ to $6.0 \mathrm{~m}$ and the slab thickness varied from $80 \mathrm{~mm}$ to $500 \mathrm{~mm}$. The average effective depth $\left(d_{\text {avg }}\right)$ of all the specimens in the database was $146 \mathrm{~mm}$ and the average reinforcement ratio was $1 \cdot 30 \%$. The centralised values are listed in Table 1 and the complete database is given in the Appendix.

\section{Comparison with codified approaches}

The codified rules propose different relationships to assess the punching shear strength. The calculations are made considering a critical section that lies at a certain distance from the face of the column. The European design code Eurocode 2 (CEN, 2004) uses a critical perimeter at $2 d$ (Equation 17a) whereas the American design code ACI 318-14 (ACI, 2014) (Equation 18) and MC2010 (fib, 2012) (Equation 19a) define the critical section at $d / 2$. In all the above methods, the punching shear strength is a function of the concrete strength $f_{\mathrm{c}}$, effective depth $d$ and the critical perimeter $b_{0}$. Eurocode 2 and MC2010 account for the influence of the flexural capacity and size effect on the punching shear strength (Equations 17b and 19b). MC2010 considers that the governing parameter in assessing the punching strength is the rotation of the slab $\psi$ (Equation 19c).

17a. $\quad V_{\mathrm{R}, \mathrm{EC} 2}=0.18 \xi\left(100 \rho_{1} f_{\mathrm{c}}\right)^{1 / 3} b_{0} d$

17b. $\xi=1+(200 / d)^{1 / 2}$

18. $V_{\mathrm{R}, \mathrm{ACI}}=0.33 b_{0} d\left(f_{\mathrm{c}}\right)^{1 / 2}$

19a. $\quad V_{\mathrm{R}, \mathrm{MC} 2010}=k_{\psi}\left(f_{\mathrm{c}}\right)^{1 / 2} b_{0} d$

19b. $k_{\psi}=1 /\left(1.5+0.6 \psi d k_{\mathrm{dg}}\right)$

19c. $\psi=1.5 \frac{r_{\mathrm{s}, i}}{d} \frac{f_{\mathrm{yd}}}{E_{\mathrm{s}}}\left(\frac{m_{\mathrm{sd}, i}}{m_{\mathrm{rd}, i}}\right)^{3 / 2}$ 


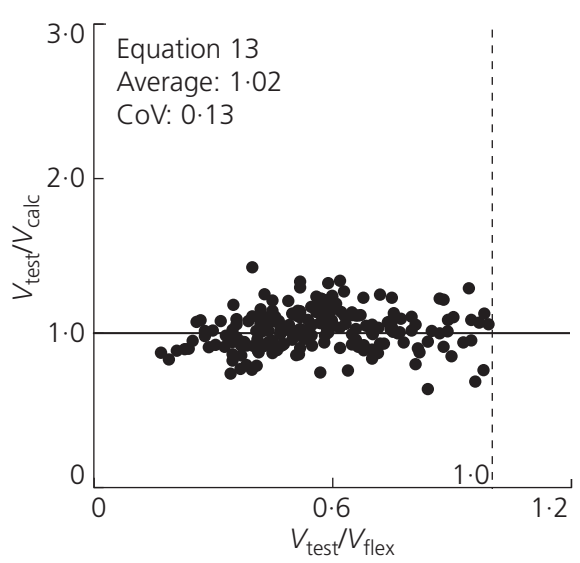

(a)

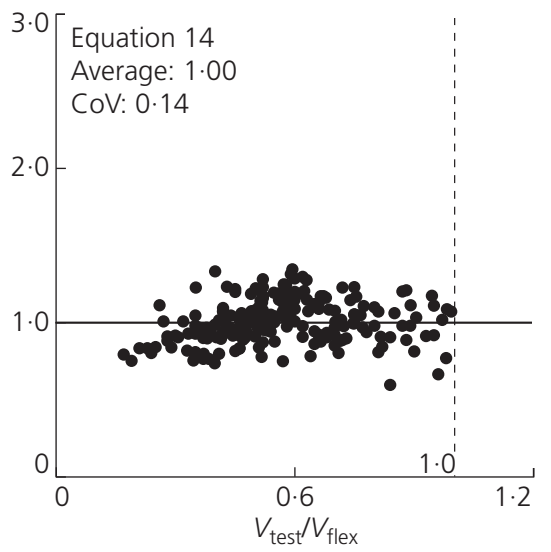

(b)

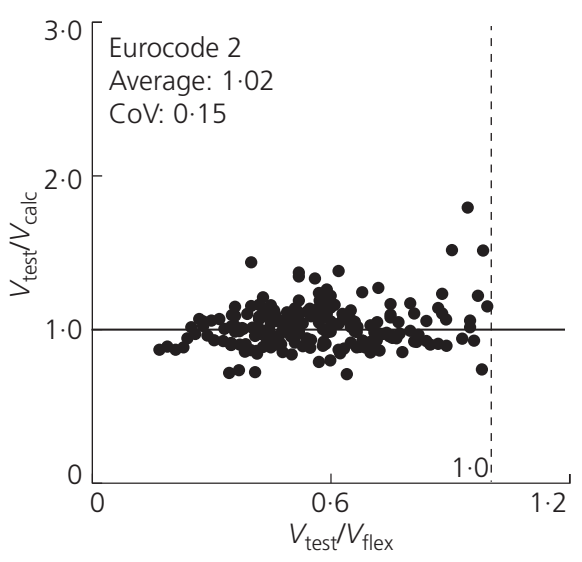

(c)

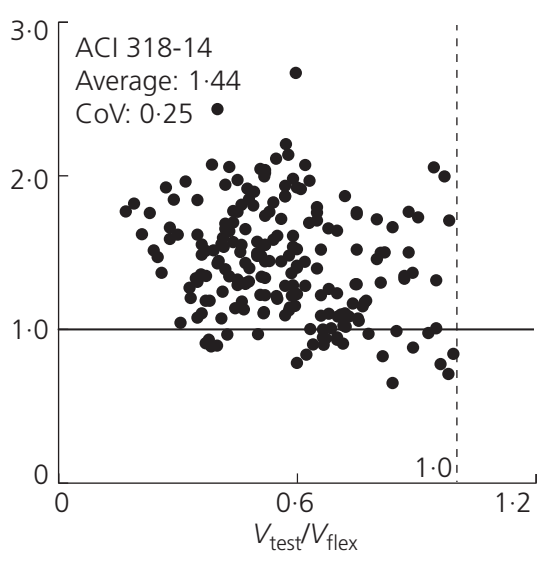

(d)

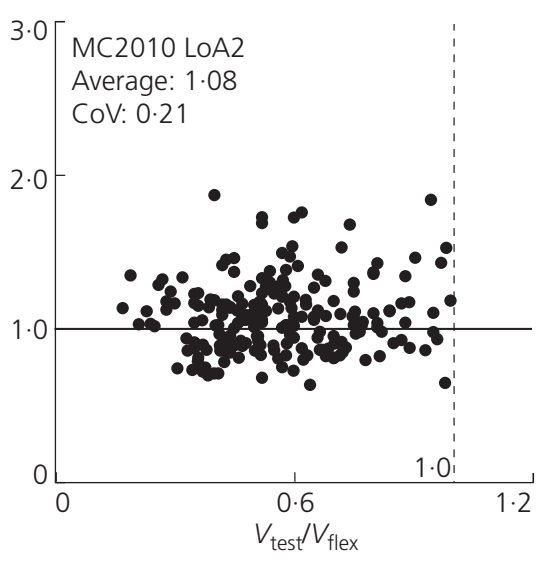

(e)

Figure 8. Prediction of ultimate punching shear strength according to: (a) the proposed method (Equation 13); (b) the proposed method (Equation 14); (c) Eurocode 2; (d) ACI 318-14; (e) MC2010 (LoA2)

In these equations, $k_{\mathrm{dg}}$ is a factor that is dependent on the maximum aggregate dimension $\left(k_{\mathrm{dg}}=32 /\left(16+d_{\mathrm{g}}\right)\right), \quad r_{\mathrm{s}}$ is the distance between zero moment and load application point, $d$ is the effective depth, $f_{\mathrm{yd}}$ is the design yield strength of bending reinforcement, $E_{\mathrm{s}}$ is the modulus of elasticity for rebars, $m_{\mathrm{sd}}$ is the average bending moment acting in the support strip and $m_{\mathrm{rd}}$ is the flexural strength per unit length in the support strip.

The results in Table 1 show the punching shear strength predictions $V_{\text {calc }}$ of the codified approaches and the proposed method in relation to the reported strength $V_{\text {test }}$ on a database of 209 isolated interior flat-slab column connections. The specimens are grouped on the basis of the author or research group that carried out the investigation. The table plots the number of specimens per author/group, the minimum and maximum values of effective depth $d$, flexural reinforcement ratio $\rho$, concrete compressive strength $f_{\mathrm{c}}$, steel yield strength $f_{\mathrm{y}}$ and the statistical parameters (average and coefficient of variance $(\mathrm{CoV}))$ for the reported to predicted ultimate punching shear strengths $V_{\text {test }} / V_{\text {calc }}$. The case when the reported strength is smaller than the predicted strength is represented by a $V_{\text {test }} / V_{\text {calc }}$ value less than $1 \cdot 00$. The statistical parameters are plotted for each group of specimens. All the reported data, including the ultimate strength $V_{\text {test }}$, structural parameters of each specimen and statistical parameters as result of computed predictions, are given in the Appendix.

The proposed method (Equation 13) shows an average $V_{\text {test }} / V_{\text {calc }}$ of 1.02 and a $\mathrm{CoV}$ of 0.13 (Figure $8(\mathrm{a})$ ), while the condensed form (Equation 14) shows a $V_{\text {test }} / V_{\text {calc }}$ ratio of 1.00 and a slightly higher $\mathrm{CoV}$ of $0 \cdot 14$ (Figure $8(\mathrm{~b})$ ). In both cases, the prediction offered by the proposed method offer good predictions of the ultimate punching shear strength. Figure 8 also shows a comparison between 


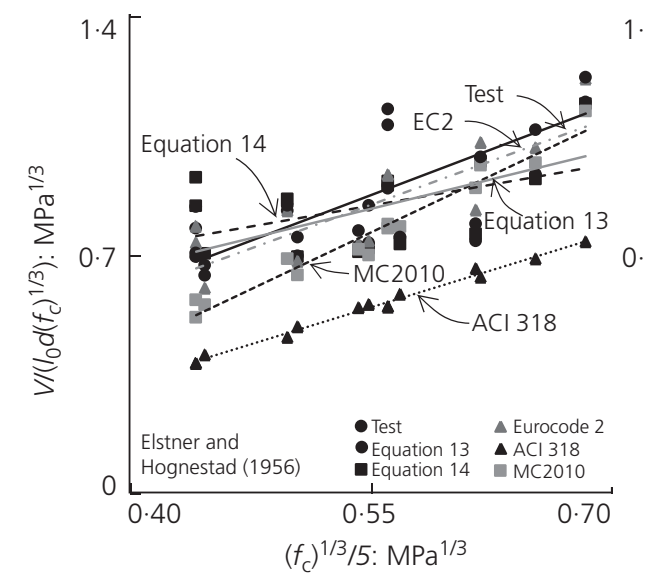

(a)

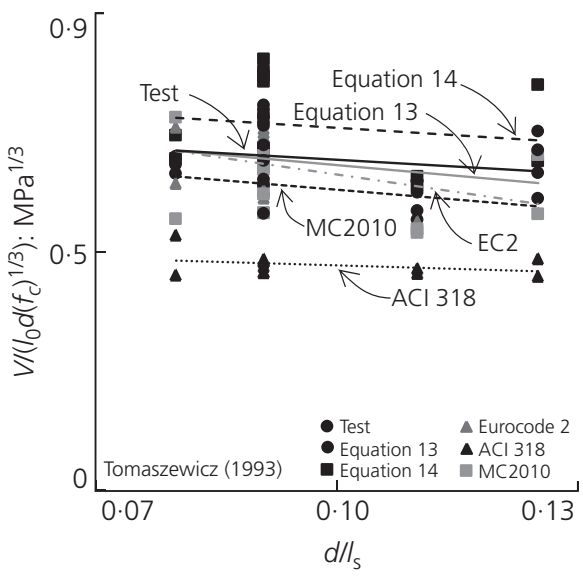

(d)

Figure 9. Predictions and trend curves for a series of selected tests according to the proposed model and current design procedures: (a) concrete strength; (b) reinforcement ratio for

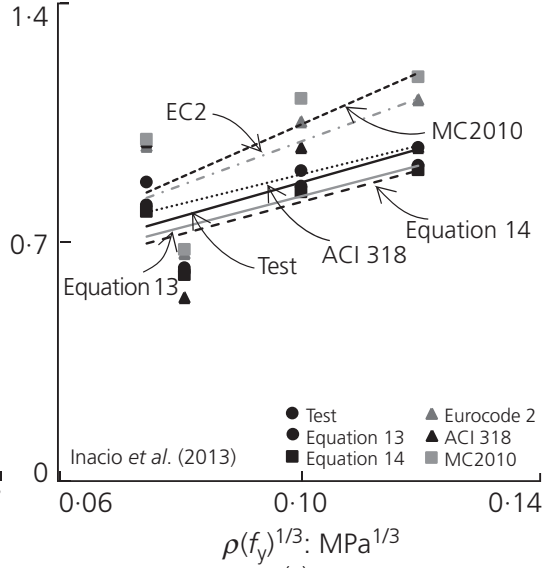

(C)

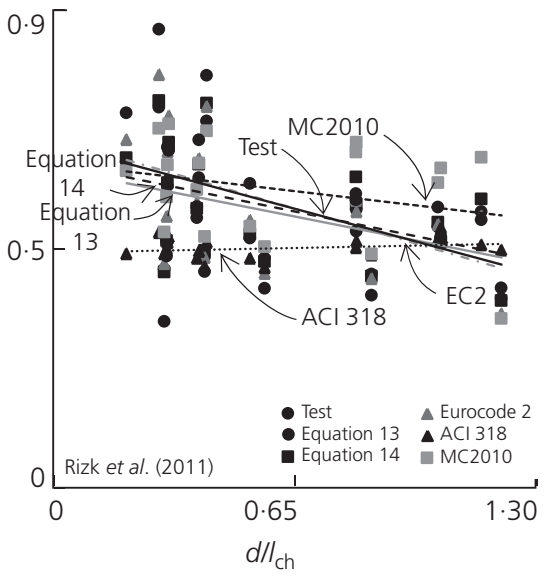

(e)

normal-strength concrete; (c) reinforcement ratio for high-strength concrete; (d) slenderness of the slab; (e) size effect (concrete fractal parameter)

the condensed form (Equation 14) and current design codes (Eurocode 2 (Equation 17a), ACI 318-14 (Equation 18) and MC2010 level II of approximation (LoA2) (Equation 19a). The proposed Equation 14 shows notable outcomes regarding the statistical parameters (average and $\mathrm{CoV}$ ). Eurocode 2 (CEN, 2004) shows a similar CoV (0.15) and average (1.02) with a slight tendency to overestimate the ultimate strength for low reinforcement ratios (i.e. large $V_{\text {test }} /$ $V_{\text {flex }}$ ). ACI 318-14 (ACI, 2014) offers conservative predictions ( $\mathrm{CoV}$ of 0.25 and average of 1.44 ). The scatter points tend to reproduce the decreasing trend of the computed values, leading to higher predicted values than those reported in tests. For a similar level of refinement, MC2010 (LoA2) offers slightly more conservative results compared with the proposed method. However, a higher degree of refinement is available in MC2010 and hence better statistical parameters may be obtained (Muttoni and Fernandez Ruiz, 2012).

\section{Parametric comparisons}

This section compares the proposed method and the existing guidelines with regard to a series of key structural parameters. Figure 9(a) presents the capability of the proposed method to follow the contribution of concrete to the punching shear strength. Elstner and Hognestad (1956) carried out a series of tests on rectangular slabs in which the varying parameter was concrete strength. The figure shows that the proposed method follows the relationship between concrete strength and normalised strength in a satisfactory way.

Figures 9(b) and 9(c) plot the relationship between the flexural characteristics of the slab and the ultimate strength (in normalised values) of normal-strength concrete (Kinnunen and Nylander, 1960) and high-strength concrete (Inacio et al., 2013). Variation of the reinforcement ratio from low to high ( $0 \cdot 54 \%$ to $2 \cdot 10 \%$ and $0 \cdot 94 \%$ to $1 \cdot 49 \%$ respectively) reveals excellent agreement between the predicted and reported 
strengths for both extreme cases of concrete strength $(\approx 29 \cdot 3$ $\mathrm{MPa}$ and $\approx 129 \mathrm{MPa}$ respectively). The other design methods show a similar response, but ACI 318-14 shows a contrasting trend. The influence of the reinforcement ratio and steel yield strength is estimated by a nearly constant line due to the fact that formulation of the code rules of ACI 318-14 does not include flexural characteristics of the slab.

The influence of the slenderness of the slab is best captured by Equation 13 (Figure 9(d)), which closely predicts the ultimate punching strength from the tests reported by Tomaszewicz (1993). The size effect is emphasised by means of the fractal parameter of concrete $\left(l_{\mathrm{ch}}\right)$ and effective depth $(d)$ from tests carried out by Marzouk and Hussein (1991) and Rizk et al., (2011) (Figure 9(e)). Although all the results show a similar trend of the normalised strength in relation to $d / l_{\mathrm{ch}}$, the actual behaviour is better anticipated by the proposed method (Equations 13 and 14) and Eurocode 2 for small fractal values $\left(l_{\mathrm{ch}}\right)$.

\section{Concluding remarks}

A method is proposed to evaluate the punching shear strength of RC flat slabs without shear reinforcement at the connection to interior columns. The method is based on the assumption that punching shear strength is controlled by the inclination of a unique punching shear crack that produces a conical failure surface. The inclination angle is variable and therefore the location of the critical section is not predefined. The method was verified on a database of 209 tests on isolated specimens reported in literature. It shows notable agreement with the test results regarding both the influence of key structural parameters and statistical parameters compared with codified provisions (average and CoV). The method offers safe estimates since the beneficial effect of compressive membrane action is disregarded. Taking account of information obtained in tests (Bompa and Oneț, 2011; Gosav et al., 2013) and the findings from the numerical and analytical investigations, the conclusions can be summarised as follows.

- According to the proposed method, punching shear failure is described by the development of a unique punching shear crack with variable inclination, producing a conical failure surface. The parameters that control crack inclination are the flexural reinforcement ratio, slab thickness and concrete and reinforcement steel strengths. The inclination of the crack determines the amount of shear carried by specific concrete shear transfer actions.

- Considering experimental observations and reported crosssectional crack patterns, the cracks tend to form at flatter angles for low reinforcement ratios and at steeper ones for high reinforcement ratios.

- The numerical investigations show that an increase in slab thickness produces a proportional increase in the angle of the compression stress field and consequently in the inclination of the punching shear crack.

- Based on the reported results in the test database, the structural parameters that control the behaviour of flat slabs at ultimate state are flexural characteristics (proportional increase of punching strength for an increase in reinforcement ratio), slenderness of the slab (increase in strength with decrease in slenderness) and concrete strength (decreasing normalised punching shear strength with increasing concrete strength for low and moderate reinforcement ratios).

- The punching shear strength of flat slabs without shear reinforcement at the connection to interior columns is calculated as a function of the crack inclination $(\theta)$, effective depth $(d)$, concrete strength $\left(f_{\mathrm{c}}\right)$, reinforcement ratio and strength ( $\rho$ and $f_{\mathrm{y}}$ ) and column dimension $\left(b_{\mathrm{c}}\right)$. The method accounts for the characteristic concrete size effect by considering the ratio of effective depth $d$ to fractal parameter $l_{\mathrm{ch}}$.

- Accounting for a variable inclination of the crack, the proposed method offers good predictions of the ultimate punching shear strength for extreme geometrical and material configurations such as low reinforcement ratios and high-strength concretes. The results, based on a series of 209 tests, show an average of 1.00 and $\mathrm{CoV}$ of $0 \cdot 14$ for the condensed form of the method (Equation 14) and an average of 1.02 and a $\mathrm{CoV}$ of 0.13 for the extended form (Equation 13).

- The European provision Eurocode 2 (CEN, 2004) shows a similar $\mathrm{CoV}$ and a slight tendency to overestimate the ultimate strength for low reinforcement ratios (i.e. large values of $\left.V_{\text {test }} / V_{\text {flex }}\right)$. The American design guideline ACI 318-14 (ACI, 2014) offers conservative predictions (CoV of 0.25 and average of 1.44 ). The scatter points tend to reproduce the decreasing trend of the computed values, leading to higher predicted values than those reported in tests. For a similar level of refinement, Model Code 2010 (LoA2) (fib, 2012) offers slightly more conservative results than the proposed method (average of 1.08 and $\mathrm{CoV}$ of $0 \cdot 21)$.

\section{Acknowledgements}

The financial support of ESF through the EU-funded project Prodoc at Technical University of Cluj-Napoca, Romania is gratefully acknowledged by the authors (where the early stage of the work was carried out). Additionally, the first author would like to thank to Professor A. R. Marí Bernat and Professor J. M. Bairan García from Universitat Politècnica de Catalunya for their valuable comments and suggestions regarding the work carried out and reported in this paper during the research mobility stage spent at their department. 


\begin{tabular}{|c|c|c|c|c|c|c|c|c|c|c|c|}
\hline \multirow[b]{2}{*}{ Specimen } & \multirow[b]{2}{*}{$d: \mathrm{mm}$} & \multirow[b]{2}{*}{$\rho$} & \multirow[b]{2}{*}{$f_{c}: \mathrm{MPa}$} & \multirow[b]{2}{*}{$d_{g}: m m$} & \multirow[b]{2}{*}{$f_{\mathrm{y}}: \mathrm{MPa}$} & \multirow[b]{2}{*}{$V_{u, \text { test }}: \mathrm{kN}$} & \multicolumn{5}{|c|}{$V_{\mathrm{R}, \text { cald }} / V_{\mathrm{u} \text {,test }}$} \\
\hline & & & & & & & Equation 13 & Equation 14 & Eurocode 2 & $\begin{array}{c}\mathrm{ACl} \\
318-14 \\
\end{array}$ & $\begin{array}{c}\text { MC2010 } \\
\text { (LoA2) }\end{array}$ \\
\hline \multicolumn{12}{|l|}{ Hallgren (1996) } \\
\hline $\mathrm{HSCO}$ & 200 & 0.008 & $89 \cdot 2$ & 18 & 643 & 965 & 0.87 & 0.80 & 0.98 & $1 \cdot 10$ & 0.91 \\
\hline $\mathrm{HSC} 1$ & 200 & 0.008 & $86 \cdot 7$ & 18 & 627 & 1021 & 1.00 & 0.97 & 1.05 & $1 \cdot 18$ & 1.02 \\
\hline $\mathrm{HSC} 2$ & 194 & 0.008 & $81 \cdot 4$ & 18 & 620 & 889 & 0.93 & 0.89 & 0.97 & $1 \cdot 10$ & 0.91 \\
\hline $\mathrm{HSC} 4$ & 200 & 0.012 & $87 \cdot 0$ & 18 & 596 & 1041 & 0.92 & $0 \cdot 87$ & 0.93 & $1 \cdot 20$ & $0 \cdot 86$ \\
\hline HSC6 & 201 & 0.006 & 103 & 18 & 633 & 960 & 0.95 & 0.92 & 1.01 & 1.00 & 0.98 \\
\hline N/HSC8 & 198 & 0.008 & $90 \cdot 2$ & 18 & 631 & 944 & 0.93 & 0.90 & 0.97 & $1 \cdot 08$ & 0.88 \\
\hline \multicolumn{12}{|c|}{ Tomaszewicz (1993) } \\
\hline ND65-1-1 & 275 & 0.015 & $64 \cdot 1$ & 16 & 500 & 2050 & 1.09 & 0.96 & $1 \cdot 15$ & 1.48 & $1 \cdot 15$ \\
\hline ND65-2-1 & 200 & 0.017 & $70 \cdot 0$ & 16 & 500 & 1200 & 1.05 & 0.94 & 1.09 & $1 \cdot 55$ & $1 \cdot 23$ \\
\hline ND95-1-1 & 275 & 0.015 & $83 \cdot 5$ & 16 & 500 & 2250 & $1 \cdot 11$ & 0.99 & $1 \cdot 15$ & 1.43 & $1 \cdot 19$ \\
\hline ND95-1-3 & 275 & 0.025 & $89 \cdot 7$ & 16 & 500 & 2400 & 0.95 & 0.84 & 1.01 & 1.47 & 1.01 \\
\hline ND95-2-1 & 200 & 0.017 & 88.0 & 16 & 500 & 1100 & 0.91 & 0.82 & 0.92 & $1 \cdot 27$ & 0.93 \\
\hline ND95-2-1D & 200 & 0.017 & $86 \cdot 5$ & 16 & 500 & 1300 & 1.08 & 0.96 & $1 \cdot 10$ & $1 \cdot 51$ & $1 \cdot 19$ \\
\hline ND95-2-3 & 200 & 0.026 & $89 \cdot 3$ & 16 & 500 & 1450 & 1.01 & 0.91 & 1.05 & 1.66 & $1 \cdot 18$ \\
\hline ND95-2-3D & 200 & 0.026 & $80 \cdot 1$ & 16 & 500 & 1250 & 0.90 & $0 \cdot 80$ & 0.94 & $1 \cdot 51$ & 1.03 \\
\hline ND95-2-3D+ & 200 & 0.026 & $97 \cdot 8$ & 16 & 500 & 1450 & 0.98 & 0.88 & 1.02 & 1.59 & $1 \cdot 12$ \\
\hline ND95-3-1 & 88 & 0.018 & $84 \cdot 9$ & 16 & 500 & 330 & 1.02 & 1.00 & 0.91 & $1 \cdot 30$ & 0.89 \\
\hline ND115-1-1 & 275 & 0.015 & 112 & 16 & 500 & 2450 & $1 \cdot 10$ & 0.98 & $1 \cdot 14$ & $1 \cdot 34$ & $1 \cdot 16$ \\
\hline ND115-2-1 & 200 & 0.017 & 119 & 16 & 500 & 1400 & 1.05 & 0.94 & 1.06 & $1 \cdot 39$ & $1 \cdot 12$ \\
\hline ND115-2-3 & 200 & 0.026 & 108 & 16 & 500 & 1550 & 1.01 & 0.91 & 1.06 & $1 \cdot 62$ & $1 \cdot 16$ \\
\hline \multicolumn{12}{|c|}{ Marzouk and Hussein (1991) and Rizk et al. (2011) } \\
\hline I.NS1 & 95 & 0.0147 & $42 \cdot 0$ & 20 & 490 & 320 & $1 \cdot 15$ & $1 \cdot 14$ & 1.08 & 1.61 & $1 \cdot 18$ \\
\hline I.HS1 & 95 & 0.0049 & $67 \cdot 0$ & 20 & 490 & 178 & 0.76 & 0.77 & 0.74 & $0 \cdot 71$ & 0.65 \\
\hline I.HS2 & 95 & 0.0084 & $70 \cdot 0$ & 20 & 490 & 249 & 0.94 & 0.94 & 0.85 & 0.97 & 0.80 \\
\hline I.HS7 & 95 & 0.0193 & 74.0 & 20 & 490 & 356 & 1.00 & 0.98 & 0.91 & $1 \cdot 35$ & 0.93 \\
\hline I.HS3 & 95 & 0.0147 & $69 \cdot 0$ & 20 & 490 & 356 & $1 \cdot 13$ & $1 \cdot 12$ & 1.01 & $1 \cdot 39$ & 1.06 \\
\hline I.HS4 & 90 & 0.0237 & 66.0 & 20 & 490 & 418 & 1.21 & $1 \cdot 19$ & $1 \cdot 11$ & 1.80 & 1.28 \\
\hline II.HS5 & 125 & 0.0064 & $68 \cdot 0$ & 20 & 490 & 365 & 0.94 & 0.91 & 0.94 & 0.98 & 0.86 \\
\hline II.HS7 & 120 & 0.0094 & 74.0 & 20 & 490 & 489 & $1 \cdot 22$ & $1 \cdot 20$ & $1 \cdot 14$ & $1 \cdot 33$ & $1 \cdot 16$ \\
\hline II.HS8 & 120 & 0.0111 & $69 \cdot 0$ & 20 & 490 & 436 & 1.04 & 1.01 & 0.98 & $1 \cdot 23$ & 0.94 \\
\hline II.HS9 & 120 & 0.0161 & 74.0 & 20 & 490 & 543 & $1 \cdot 12$ & 1.08 & 1.06 & 1.48 & 1.07 \\
\hline II.HS10 & 120 & 0.0233 & $80 \cdot 0$ & 20 & 490 & 645 & $1 \cdot 12$ & 1.07 & 1.08 & 1.69 & $1 \cdot 16$ \\
\hline NS2 & 218 & 0.0073 & $40 \cdot 0$ & 19 & 400 & 882 & 0.87 & 0.88 & 0.93 & 0.90 & 0.83 \\
\hline HS2 & 218 & 0.0073 & $64 \cdot 7$ & 19 & 400 & 1023 & 0.90 & 0.91 & 0.92 & 0.82 & 0.82 \\
\hline HS3 & 263 & 0.0144 & $65 \cdot 4$ & 19 & 400 & 2090 & 1.01 & 1.02 & 0.97 & 0.96 & 0.78 \\
\hline NS3 & 313 & 0.0157 & $40 \cdot 0$ & 19 & 400 & 2234 & 0.92 & 0.90 & 0.93 & 1.04 & 0.74 \\
\hline HSS1 & 268 & 0.0050 & $76 \cdot 0$ & 19 & 460 & 1722 & 1.06 & 1.07 & $1 \cdot 15$ & 0.84 & $1 \cdot 18$ \\
\hline HSS3 & 263 & 0.0142 & 65.0 & 19 & 460 & 2090 & 1.08 & 1.06 & 1.07 & $1 \cdot 13$ & 0.92 \\
\hline NSS1 & 313 & 0.0158 & $40 \cdot 0$ & 19 & 460 & 2234 & 0.98 & 0.93 & 1.00 & $1 \cdot 20$ & 0.86 \\
\hline JSS4 & 313 & 0.0158 & $60 \cdot 0$ & 19 & 460 & 2513 & 0.97 & 0.93 & 0.98 & $1 \cdot 10$ & 0.81 \\
\hline \multicolumn{12}{|l|}{ Regan (1986) } \\
\hline $1 / 1$ & 77 & 0.0120 & $25 \cdot 4$ & 10 & 500 & 194 & 1.07 & $1 \cdot 11$ & 0.97 & $1 \cdot 37$ & $1 \cdot 28$ \\
\hline $1 / 2$ & 77 & 0.0120 & $23 \cdot 1$ & 10 & 500 & 176 & 0.99 & 1.02 & 0.91 & $1 \cdot 30$ & $1 \cdot 16$ \\
\hline $1 / 3$ & 77 & 0.0092 & $27 \cdot 1$ & 10 & 500 & 194 & $1 \cdot 14$ & $1 \cdot 21$ & 1.04 & $1 \cdot 32$ & 1.46 \\
\hline $1 / 4$ & 77 & 0.0092 & $31 \cdot 9$ & 10 & 500 & 194 & $1 \cdot 10$ & $1 \cdot 17$ & 0.98 & $1 \cdot 22$ & $1 \cdot 33$ \\
\hline $1 / 5$ & 79 & 0.0075 & $27 \cdot 8$ & 10 & 480 & 165 & 0.97 & 1.04 & 0.91 & 1.08 & $1 \cdot 17$ \\
\hline $1 / 6$ & 79 & 0.0075 & 21.6 & 10 & 480 & 165 & 1.02 & 1.09 & 0.99 & $1 \cdot 22$ & $1 \cdot 35$ \\
\hline $1 / 7$ & 79 & 0.0080 & $30 \cdot 0$ & 10 & 480 & 186 & 1.07 & $1 \cdot 14$ & 0.98 & $1 \cdot 17$ & 1.68 \\
\hline
\end{tabular}

Table A1. (continued on next page) 


\begin{tabular}{|c|c|c|c|c|c|c|c|c|c|c|c|}
\hline \multirow[b]{2}{*}{ Specimen } & \multirow[b]{2}{*}{$d: \mathrm{mm}$} & \multirow[b]{2}{*}{$\rho$} & \multirow[b]{2}{*}{$f_{\mathrm{c}}: \mathrm{MPa}$} & \multirow[b]{2}{*}{$d_{g}: m m$} & \multirow[b]{2}{*}{$f_{\mathrm{y}}: \mathrm{MPa}$} & \multirow[b]{2}{*}{$V_{u, \text { test }}: \mathrm{kN}$} & \multicolumn{5}{|c|}{$V_{R, \text { cald }} / V_{u, \text { test }}$} \\
\hline & & & & & & & Equation 13 & Equation 14 & Eurocode 2 & $\begin{array}{c}\mathrm{ACl} \\
318-14\end{array}$ & $\begin{array}{c}\text { MC2010 } \\
\text { (LoA2) }\end{array}$ \\
\hline$\| / 1$ & 200 & 0.0100 & 34.4 & 20 & 530 & 825 & 0.94 & 0.90 & 1.00 & $1 \cdot 18$ & 0.86 \\
\hline$\| / 2$ & 128 & 0.0100 & $32 \cdot 9$ & 20 & 485 & 390 & 1.02 & 0.98 & 1.04 & $1 \cdot 40$ & 1.09 \\
\hline $11 / 3$ & 128 & 0.0100 & 33.9 & 10 & 485 & 365 & 0.95 & 0.92 & 0.97 & $1 \cdot 29$ & 0.89 \\
\hline $11 / 6$ & 64 & 0.0100 & $35 \cdot 7$ & 5 & 480 & 105 & 0.96 & 0.95 & 0.89 & 1.44 & $1 \cdot 27$ \\
\hline \multicolumn{12}{|l|}{ Moe (1961) } \\
\hline$S 1-60$ & 114 & 0.0110 & $22 \cdot 1$ & 38 & 399 & 389 & $1 \cdot 34$ & 1.29 & $1 \cdot 38$ & 2.07 & $1 \cdot 76$ \\
\hline$S 2-60$ & 114 & 0.0150 & $21 \cdot 0$ & 38 & 399 & 356 & $1 \cdot 15$ & 1.09 & $1 \cdot 16$ & 1.94 & 1.41 \\
\hline S3-60 & 114 & 0.0200 & $21 \cdot 5$ & 38 & 399 & 364 & 1.08 & 1.01 & 1.07 & 1.96 & $1 \cdot 33$ \\
\hline$S 4-60$ & 114 & 0.0260 & $22 \cdot 6$ & 38 & 399 & 334 & 0.89 & 0.83 & 0.88 & $1 \cdot 76$ & $1 \cdot 11$ \\
\hline$S 1-70$ & 114 & 0.0110 & $23 \cdot 3$ & 38 & 483 & 393 & $1 \cdot 33$ & $1 \cdot 28$ & $1 \cdot 37$ & 2.03 & 1.73 \\
\hline S3-70 & 114 & 0.0200 & $24 \cdot 1$ & 38 & 483 & 378 & 1.08 & 1.01 & 1.07 & 1.92 & $1 \cdot 32$ \\
\hline S4-70 & 114 & 0.0260 & $33 \cdot 4$ & 38 & 483 & 374 & 0.88 & 0.83 & 0.87 & 1.62 & 1.03 \\
\hline S4-70A & 114 & 0.0260 & $19 \cdot 5$ & 38 & 483 & 312 & 0.87 & 0.79 & $0 \cdot 87$ & $1 \cdot 77$ & $1 \cdot 13$ \\
\hline S5-60 & 114 & 0.0110 & $21 \cdot 1$ & 38 & 399 & 343 & $1 \cdot 19$ & $1 \cdot 15$ & $1 \cdot 24$ & 1.87 & 1.49 \\
\hline S5-70 & 114 & 0.0110 & $21 \cdot 9$ & 38 & 483 & 378 & $1 \cdot 29$ & $1 \cdot 23$ & $1 \cdot 34$ & $2 \cdot 02$ & 1.69 \\
\hline $\mathrm{R} 1$ & 114 & 0.0140 & $25 \cdot 3$ & 10 & 328 & 312 & 0.98 & 0.95 & 0.98 & $1 \cdot 55$ & $1 \cdot 23$ \\
\hline R2 & 114 & 0.0140 & $26 \cdot 2$ & 10 & 328 & 394 & $1 \cdot 23$ & $1 \cdot 20$ & $1 \cdot 22$ & 1.92 & $1 \cdot 72$ \\
\hline $\mathrm{H} 1$ & 114 & 0.0110 & $24 \cdot 8$ & 38 & 328 & 372 & $1 \cdot 25$ & $1 \cdot 22$ & $1 \cdot 27$ & 1.87 & $1 \cdot 53$ \\
\hline M1A & 114 & 0.0150 & $19 \cdot 8$ & 38 & 481 & 433 & $1 \cdot 42$ & $1 \cdot 33$ & $1 \cdot 44$ & $2 \cdot 43$ & $1 \cdot 87$ \\
\hline \multicolumn{12}{|c|}{ Kinnunen and Nylander (1960) } \\
\hline IA15a-5 & 117 & 0.0080 & $27 \cdot 6$ & 32 & 441 & 255 & 0.87 & 0.84 & 0.96 & $1 \cdot 50$ & 0.98 \\
\hline IA15a-6 & 118 & 0.0080 & $25 \cdot 4$ & 32 & 454 & 275 & 0.94 & 0.90 & 1.05 & 1.66 & $1 \cdot 11$ \\
\hline IA15c-11 & 121 & 0.0180 & $31 \cdot 0$ & 32 & 436 & 334 & 0.87 & 0.81 & 0.88 & $1 \cdot 76$ & 1.00 \\
\hline $\mid A 15 c-12$ & 122 & 0.0170 & $28 \cdot 4$ & 32 & 439 & 332 & 0.89 & 0.83 & 0.91 & $1 \cdot 81$ & 1.04 \\
\hline IA30a-24 & 128 & 0.0100 & $25 \cdot 6$ & 32 & 456 & 430 & 1.05 & 1.07 & $1 \cdot 10$ & $1 \cdot 50$ & 1.03 \\
\hline IA30a-25 & 124 & 0.0110 & $24 \cdot 3$ & 32 & 451 & 408 & 1.04 & 1.05 & 1.08 & $1 \cdot 52$ & 1.02 \\
\hline IA30c-30 & 120 & 0.0210 & $29 \cdot 2$ & 32 & 436 & 491 & 1.02 & 1.01 & 1.03 & $1 \cdot 74$ & 1.06 \\
\hline IA30c-31 & 119 & 0.0210 & $29 \cdot 2$ & 32 & 448 & 540 & $1 \cdot 14$ & $1 \cdot 13$ & $1 \cdot 14$ & 1.93 & $1 \cdot 21$ \\
\hline IA30e-34 & 120 & 0.0100 & $26 \cdot 5$ & 32 & 461 & 332 & $0 \cdot 89$ & 0.92 & 0.92 & $1 \cdot 23$ & $0 \cdot 81$ \\
\hline IA30e-35 & 122 & 0.0100 & $24 \cdot 3$ & 32 & 459 & 332 & $0 \cdot 89$ & 0.90 & 0.92 & $1 \cdot 26$ & 0.82 \\
\hline \multicolumn{12}{|c|}{ Elstner and Hognestad (1956) } \\
\hline $\mid A-1 a$ & 118 & 0.0115 & $11 \cdot 1$ & 25 & 332 & 303 & 0.96 & 0.91 & 1.06 & 1.57 & $1 \cdot 16$ \\
\hline $\mid A-1 b$ & 118 & 0.0115 & $19 \cdot 9$ & 25 & 332 & 365 & 1.06 & 1.09 & $1 \cdot 05$ & $1 \cdot 41$ & 1.08 \\
\hline $\mid A-1 C$ & 118 & 0.0115 & $22 \cdot 9$ & 25 & 332 & 356 & $1 \cdot 00$ & 1.03 & 0.98 & $1 \cdot 28$ & 0.96 \\
\hline $\mid A-1 d$ & 118 & 0.0115 & $29 \cdot 1$ & 25 & 332 & 351 & 0.94 & 0.97 & 0.89 & $1 \cdot 12$ & 0.83 \\
\hline IA-1e & 118 & 0.0115 & $16 \cdot 0$ & 25 & 332 & 356 & $1 \cdot 08$ & 1.08 & $1 \cdot 10$ & $1 \cdot 54$ & $1 \cdot 17$ \\
\hline $\mid A-2 a$ & 114 & 0.0247 & $10 \cdot 7$ & 25 & 321 & 334 & 0.91 & 0.84 & 0.96 & $1 \cdot 84$ & $1 \cdot 24$ \\
\hline $\mid A-2 b$ & 114 & 0.0247 & $15 \cdot 4$ & 25 & 321 & 400 & 1.02 & 0.98 & 1.02 & 1.84 & $1 \cdot 23$ \\
\hline $\mid A-2 C$ & 114 & 0.0247 & $29 \cdot 5$ & 25 & 321 & 467 & 1.01 & 1.01 & 0.96 & 1.55 & 1.02 \\
\hline $\mid A-7 b$ & 114 & 0.0247 & $22 \cdot 0$ & 25 & 321 & 512 & $1 \cdot 21$ & $1 \cdot 20$ & $1 \cdot 16$ & 1.97 & $1 \cdot 37$ \\
\hline$\| A-4$ & 118 & 0.0115 & $20 \cdot 6$ & 25 & 332 & 400 & $1 \cdot 15$ & $1 \cdot 17$ & $1 \cdot 14$ & $1 \cdot 52$ & $1 \cdot 21$ \\
\hline$\| A-5$ & 114 & 0.0247 & $22 \cdot 0$ & 25 & 321 & 534 & $1 \cdot 25$ & $1 \cdot 23$ & $1 \cdot 21$ & 2.06 & 1.45 \\
\hline VIII B-9 & 114 & 0.0200 & $34 \cdot 7$ & 25 & 341 & 505 & $1 \cdot 14$ & $1 \cdot 16$ & 1.05 & 1.55 & $1 \cdot 10$ \\
\hline VIII B-11 & 114 & 0.0300 & $10 \cdot 7$ & 25 & 409 & 329 & 0.83 & 0.75 & 0.89 & $1 \cdot 82$ & $1 \cdot 35$ \\
\hline VIII B-14 & 114 & 0.0300 & 39.9 & 25 & 325 & 578 & 1.06 & 1.07 & 1.00 & 1.65 & 1.09 \\
\hline \multicolumn{12}{|c|}{ Guandalini et al. (2009) } \\
\hline PG-1 & 210 & 0.0150 & $25 \cdot 7$ & 16 & 573 & 1023 & 1.07 & 0.97 & $1 \cdot 10$ & $1 \cdot 55$ & $1 \cdot 21$ \\
\hline PG-3 & 456 & 0.0033 & $31 \cdot 8$ & 16 & 520 & 2153 & 0.63 & 0.59 & 0.92 & 0.65 & $1 \cdot 12$ \\
\hline PG-6 & 96 & 0.0150 & $27 \cdot 1$ & 16 & 526 & 236 & 0.98 & 0.94 & 0.94 & $1 \cdot 58$ & $1 \cdot 29$ \\
\hline PG-7 & 100 & 0.0075 & $33 \cdot 7$ & 16 & 550 & 241 & 1.01 & 0.98 & 1.06 & $1 \cdot 37$ & $1 \cdot 17$ \\
\hline PG-10 & 210 & 0.0033 & $29 \cdot 5$ & 16 & 577 & 540 & 0.68 & 0.66 & 0.93 & $0 \cdot 77$ & 0.93 \\
\hline
\end{tabular}

Table A1. Continued 


\begin{tabular}{|c|c|c|c|c|c|c|c|c|c|c|c|}
\hline \multirow[b]{2}{*}{ Specimen } & \multirow[b]{2}{*}{$d: \mathrm{mm}$} & \multirow[b]{2}{*}{$\rho$} & \multirow[b]{2}{*}{$f_{c}: \mathrm{MPa}$} & \multirow[b]{2}{*}{$d_{g}: m m$} & \multirow[b]{2}{*}{$f_{\mathrm{y}}: \mathrm{MPa}$} & \multirow[b]{2}{*}{$V_{u, \text { test }}: \mathrm{kN}$} & \multicolumn{5}{|c|}{$V_{R, \text { cald }} / V_{\text {u, test }}$} \\
\hline & & & & & & & Equation 13 & Equation 14 & Eurocode 2 & $\begin{array}{c}\mathrm{ACl} \\
318-14\end{array}$ & $\begin{array}{c}\text { MC2010 } \\
(\text { LoA2) }\end{array}$ \\
\hline \multicolumn{12}{|c|}{ Guidotti (2010) } \\
\hline PG19 & 206 & 0.0076 & $46 \cdot 2$ & 16 & 510 & 860 & 0.91 & 0.87 & 0.98 & 1.00 & 0.98 \\
\hline PG20 & 201 & 0.0160 & $51 \cdot 7$ & 16 & 551 & 1094 & 0.96 & 0.90 & 0.97 & $1 \cdot 24$ & 0.96 \\
\hline PG23 & 199 & 0.0081 & $41 \cdot 0$ & 32 & 510 & 839 & 0.95 & 0.92 & 1.03 & 1.09 & 0.94 \\
\hline PG24 & 194 & 0.0162 & $39 \cdot 8$ & 32 & 551 & 1102 & $1 \cdot 10$ & 1.03 & $1 \cdot 12$ & $1 \cdot 50$ & $1 \cdot 12$ \\
\hline \multicolumn{12}{|c|}{ Krueger (1999) } \\
\hline POA & 121 & 0.0100 & $34 \cdot 6$ & 16 & 480 & 423 & 1.01 & 1.05 & 0.96 & 1.07 & $1 \cdot 11$ \\
\hline \multicolumn{12}{|c|}{ Sagaseta et al. (2011) } \\
\hline PT22 & 196 & 0.0082 & $67 \cdot 0$ & 16 & 552 & 989 & 1.03 & 1.02 & 1.05 & 1.02 & $1 \cdot 10$ \\
\hline PT31 & 212 & 0.0148 & $66 \cdot 3$ & 16 & 540 & 1433 & $1 \cdot 12$ & 1.08 & $1 \cdot 19$ & $1 \cdot 33$ & $1 \cdot 15$ \\
\hline \multicolumn{12}{|c|}{ Birkle and Digler (2008) } \\
\hline 1 & 124 & 0.0154 & $41 \cdot 6$ & 14 & 488 & 483 & 1.01 & 1.03 & 1.02 & $1 \cdot 22$ & 0.95 \\
\hline 7 & 190 & 0.0130 & $35 \cdot 0$ & 20 & 531 & 825 & 0.93 & 0.91 & $1 \cdot 00$ & $1 \cdot 13$ & $0 \cdot 89$ \\
\hline 10 & 260 & 0.0100 & $31 \cdot 4$ & 20 & 524 & 1046 & $0 \cdot 76$ & $0 \cdot 73$ & $0 \cdot 86$ & $0 \cdot 89$ & $0 \cdot 71$ \\
\hline \multicolumn{12}{|c|}{ Caldentey et al. (2013) } \\
\hline 1 & 200 & 0.0107 & $37 \cdot 2$ & 20 & 575 & 974 & 0.94 & 0.96 & 1.01 & 0.93 & $0 \cdot 75$ \\
\hline 2 & 200 & 0.0107 & $37 \cdot 6$ & 20 & 575 & 956 & 0.92 & 0.94 & 0.99 & 0.91 & $0 \cdot 72$ \\
\hline \multicolumn{12}{|c|}{ Swamy and Ali (1982) } \\
\hline S1 & 100 & 0.0060 & $40 \cdot 1$ & 10 & 462 & 198 & 0.83 & 0.85 & 0.85 & 0.95 & 0.95 \\
\hline S7 & 100 & 0.0070 & $37 \cdot 4$ & 10 & 462 & 222 & 0.92 & 0.93 & 0.93 & $1 \cdot 10$ & 1.08 \\
\hline \multicolumn{12}{|c|}{ Wörle (2014) } \\
\hline P1 & 155 & 0.0224 & $37 \cdot 2$ & 16 & 558 & 612 & 0.92 & $0 \cdot 86$ & 0.91 & $1 \cdot 76$ & 1.08 \\
\hline \multicolumn{12}{|c|}{ Moreno and Sarment (2013) } \\
\hline ACO & 155 & 0.0117 & $56 \cdot 1$ & 16 & 550 & 685 & $1 \cdot 00$ & 0.99 & 0.97 & $1 \cdot 10$ & $0 \cdot 89$ \\
\hline \multicolumn{12}{|c|}{ Beutel (2002) } \\
\hline P1 & 190 & 0.0081 & 21.9 & 16 & 572 & 615 & $0 \cdot 79$ & $0 \cdot 76$ & $0 \cdot 85$ & $0 \cdot 89$ & $0 \cdot 70$ \\
\hline \multicolumn{12}{|c|}{ Broms (1990) } \\
\hline 1 & 150 & 0.0091 & $23 \cdot 4$ & 16 & 681 & 435 & 0.91 & 0.90 & 1.01 & $1 \cdot 44$ & 1.02 \\
\hline Schaefers ( & & & & & & & & & & & \\
\hline 0 & 113 & 0.00800 & 21.9 & 32 & 420 & 280 & 1.06 & 1.01 & $1 \cdot 22$ & $2 \cdot 00$ & 1.43 \\
\hline 3 & 170 & 0.00600 & $22 \cdot 1$ & 32 & 450 & 460 & 0.91 & 0.88 & $1 \cdot 10$ & $1 \cdot 50$ & 1.04 \\
\hline Heinzmanr & (2012) & & & & & & & & & & \\
\hline SP1 & 294 & 0.01204 & $35 \cdot 5$ & 32 & 577 & 1710 & 0.91 & 0.85 & 1.02 & $1 \cdot 36$ & 0.79 \\
\hline Pralong (19 & & & & & & & & & & & \\
\hline P2 & 143 & 0.01500 & $35 \cdot 4$ & 16 & 558 & 628 & 1.05 & 1.04 & 1.09 & $1 \cdot 61$ & $1 \cdot 23$ \\
\hline P5 & 171 & 0.01200 & $27 \cdot 1$ & 16 & 515 & 626 & 0.90 & 0.87 & 0.99 & 1.44 & 1.04 \\
\hline Ladner (19 & d Ladne & et al. (1977) & & & & & & & & & \\
\hline 1 & 240 & 0.01400 & $36 \cdot 7$ & 16 & 528 & 1095 & 0.85 & 0.80 & 0.90 & $1 \cdot 34$ & 0.90 \\
\hline DA6 & 80 & 0.01800 & $29 \cdot 6$ & 16 & 550 & 183 & 1.01 & 0.95 & 0.93 & $1 \cdot 77$ & $1 \cdot 14$ \\
\hline DA7 & 80 & 0.01800 & $33 \cdot 1$ & 16 & 550 & 288 & $1 \cdot 27$ & $1 \cdot 27$ & $1 \cdot 10$ & 1.69 & $1 \cdot 19$ \\
\hline DA10 & 80 & 0.01800 & $31 \cdot 6$ & 16 & 550 & 281 & $1 \cdot 18$ & $1 \cdot 20$ & 1.00 & $1 \cdot 48$ & 1.02 \\
\hline DA11 & 80 & 0.01800 & $30 \cdot 0$ & 16 & 550 & 324 & $1 \cdot 24$ & $1 \cdot 28$ & 1.01 & $1 \cdot 40$ & 1.02 \\
\hline P1 & 240 & 0.01300 & $27 \cdot 6$ & 32 & 544 & 1662 & $1 \cdot 23$ & $1 \cdot 19$ & $1 \cdot 33$ & $1 \cdot 72$ & $1 \cdot 27$ \\
\hline M1 & 109 & 0.01200 & $31 \cdot 4$ & 32 & 541 & 362 & $1 \cdot 11$ & $1 \cdot 11$ & $1 \cdot 12$ & $1 \cdot 71$ & 1.07 \\
\hline Bompa anc & $(2011)$ & nd Gosav e & tal. (2013 & & & & & & & & \\
\hline DB5 & 155 & 0.00500 & $35 \cdot 1$ & 16 & 465 & 495 & 0.85 & 0.81 & 1.02 & 0.90 & 0.86 \\
\hline$A G 1$ & 157 & 0.01370 & $17 \cdot 5$ & 16 & 583 & 570 & 1.03 & 0.98 & 1.04 & $1 \cdot 44$ & 1.08 \\
\hline$A G 2$ & 187 & 0.01260 & $19 \cdot 2$ & 16 & 583 & 872 & $1 \cdot 23$ & $1 \cdot 16$ & $1 \cdot 24$ & 1.66 & $1 \cdot 31$ \\
\hline$A G 3$ & 217 & 0.01200 & $19 \cdot 8$ & 16 & 583 & 778 & 0.89 & 0.83 & 0.90 & $1 \cdot 18$ & 0.81 \\
\hline
\end{tabular}

Table A1. Continued 


\begin{tabular}{|c|c|c|c|c|c|c|c|c|c|c|c|}
\hline \multirow[b]{2}{*}{ Specimen } & \multirow[b]{2}{*}{$d: \mathrm{mm}$} & \multirow[b]{2}{*}{$\rho$} & \multirow[b]{2}{*}{$f_{c}: M P a$} & \multirow[b]{2}{*}{$d_{g}: m m$} & \multirow[b]{2}{*}{$f_{\mathrm{y}}: \mathrm{MPa}$} & \multirow[b]{2}{*}{$V_{u, \text { test }}: k N$} & \multicolumn{5}{|c|}{$V_{\mathrm{R}, \text { cald }} / V_{\mathrm{u}, \text { test }}$} \\
\hline & & & & & & & Equation 13 & Equation 14 & Eurocode 2 & $\begin{array}{c}\mathrm{ACl} \\
318-14\end{array}$ & $\begin{array}{c}\text { MC2010 } \\
\text { (LoA2) }\end{array}$ \\
\hline \multicolumn{12}{|c|}{ Inacio et al. (2013) } \\
\hline NS & 105 & 0.01000 & $35 \cdot 9$ & $13 \cdot 9$ & 523 & 289 & 0.98 & 1.01 & 0.92 & $1 \cdot 14$ & 0.90 \\
\hline HS1 & 104 & 0.00940 & 126 & $13 \cdot 9$ & 493 & 413 & 1.08 & $1 \cdot 11$ & $0 \cdot 89$ & $0 \cdot 88$ & $0 \cdot 87$ \\
\hline HS2 & 102 & 0.01240 & 130 & $13 \cdot 9$ & 523 & 429 & 1.05 & 1.07 & $0 \cdot 86$ & 0.93 & $0 \cdot 81$ \\
\hline HS3 & 102 & 0.01480 & 130 & $13 \cdot 9$ & 523 & 461 & 1.06 & 1.07 & $0 \cdot 87$ & 1.00 & $0 \cdot 82$ \\
\hline \multicolumn{12}{|c|}{ Ramadane (1996) } \\
\hline 3 & 98 & 0.00600 & $26 \cdot 5$ & 10 & 550 & 169 & $0 \cdot 80$ & $0 \cdot 81$ & 0.92 & $1 \cdot 30$ & 1.01 \\
\hline 12 & 98 & 0.01300 & $59 \cdot 6$ & 10 & 550 & 319 & 0.99 & 0.96 & 1.03 & $1 \cdot 64$ & $1 \cdot 18$ \\
\hline 13 & 98 & 0.01300 & $43 \cdot 1$ & 10 & 550 & 297 & 0.99 & 0.94 & 1.06 & $1 \cdot 80$ & $1 \cdot 27$ \\
\hline 14 & 98 & 0.01300 & $60 \cdot 0$ & 10 & 550 & 341 & 1.08 & 1.05 & 1.09 & $1 \cdot 75$ & $1 \cdot 30$ \\
\hline 16 & 98 & 0.01300 & $97 \cdot 2$ & 10 & 550 & 362 & 1.01 & 0.98 & 0.99 & $1 \cdot 46$ & $1 \cdot 10$ \\
\hline 21 & 98 & 0.01300 & $41 \cdot 4$ & 20 & 650 & 286 & $1 \cdot 01$ & 0.99 & $1 \cdot 04$ & $1 \cdot 76$ & $1 \cdot 12$ \\
\hline 22 & 98 & 0.01300 & $83 \cdot 2$ & 20 & 650 & 405 & $1 \cdot 23$ & $1 \cdot 23$ & $1 \cdot 17$ & $1 \cdot 76$ & $1 \cdot 24$ \\
\hline 23 & 100 & 0.00900 & $55 \cdot 7$ & 20 & 650 & 341 & $1 \cdot 21$ & $1 \cdot 21$ & $1 \cdot 23$ & $1 \cdot 76$ & $1 \cdot 34$ \\
\hline 25 & 100 & 0.01200 & 32.5 & 10 & 650 & 244 & 0.91 & 0.89 & 0.96 & 1.65 & 1.09 \\
\hline 26 & 100 & 0.01200 & $37 \cdot 1$ & 20 & 650 & 294 & 1.06 & 1.04 & $1 \cdot 10$ & $1 \cdot 86$ & $1 \cdot 21$ \\
\hline 27 & 102 & 0.01000 & $33 \cdot 3$ & 20 & 650 & 227 & $0 \cdot 86$ & $0 \cdot 84$ & 0.91 & $1 \cdot 48$ & 0.92 \\
\hline \multicolumn{12}{|c|}{ Mongi (1990) } \\
\hline A1 & 78 & 0.01470 & $21 \cdot 0$ & 20 & 480 & 176 & $1 \cdot 19$ & $1 \cdot 16$ & $1 \cdot 19$ & $2 \cdot 67$ & 1.53 \\
\hline B1 & 78 & 0.01470 & $29 \cdot 8$ & 20 & 480 & $160 \cdot 6$ & 0.98 & 0.96 & 0.96 & $2 \cdot 04$ & $1 \cdot 14$ \\
\hline B2 & 78 & 0.01470 & $29 \cdot 8$ & 20 & 480 & $150 \cdot 4$ & 0.92 & 0.90 & 0.90 & 1.91 & 1.06 \\
\hline $\mathrm{C} 1$ & 78 & 0.01470 & $29 \cdot 6$ & 20 & 480 & 200 & $1 \cdot 10$ & $1 \cdot 13$ & 1.07 & 1.99 & $1 \cdot 16$ \\
\hline $\mathrm{C} 2$ & 78 & 0.01470 & $29 \cdot 6$ & 20 & 480 & $221 \cdot 2$ & $1 \cdot 22$ & $1 \cdot 25$ & $1 \cdot 19$ & $2 \cdot 21$ & $1 \cdot 32$ \\
\hline $\mathrm{C} 3$ & 78 & 0.01470 & $29 \cdot 6$ & 20 & 480 & $211 \cdot 5$ & $1 \cdot 17$ & $1 \cdot 19$ & $1 \cdot 13$ & $2 \cdot 11$ & $1 \cdot 24$ \\
\hline $\mathrm{C} 4$ & 78 & 0.01470 & $29 \cdot 6$ & 20 & 480 & $185 \cdot 1$ & 1.02 & 1.04 & 0.99 & 1.85 & 1.06 \\
\hline C5 & 78 & 0.01470 & $33 \cdot 4$ & 20 & 480 & $163 \cdot 5$ & $0 \cdot 87$ & 0.89 & $0 \cdot 84$ & 1.53 & 0.86 \\
\hline C6 & 78 & 0.01470 & $33 \cdot 4$ & 20 & 480 & $227 \cdot 5$ & $1 \cdot 21$ & $1 \cdot 24$ & $1 \cdot 17$ & $2 \cdot 14$ & $1 \cdot 28$ \\
\hline$C 7$ & 78 & 0.01470 & 29.6 & 20 & 480 & $133 \cdot 4$ & 0.74 & 0.75 & 0.72 & $1 \cdot 33$ & 0.73 \\
\hline $\mathrm{C} 8$ & 78 & 0.01470 & $30 \cdot 6$ & 20 & 480 & 167 & 0.91 & 0.93 & $0 \cdot 89$ & 1.64 & 0.92 \\
\hline C9 & 78 & 0.01470 & $30 \cdot 6$ & 20 & 380 & $200 \cdot 4$ & $1 \cdot 11$ & $1 \cdot 15$ & 1.06 & 1.96 & $1 \cdot 16$ \\
\hline C10 & 78 & 0.02940 & $33 \cdot 4$ & 20 & 380 & $220 \cdot 8$ & 0.92 & 0.92 & 0.90 & $2 \cdot 07$ & $1 \cdot 14$ \\
\hline C11 & 78 & 0.01470 & $29 \cdot 6$ & 20 & 480 & 170 & 0.94 & 0.96 & 0.91 & 1.69 & 0.96 \\
\hline C12 & 78 & 0.01470 & $29 \cdot 6$ & 20 & 480 & 160 & 0.88 & 0.90 & $0 \cdot 86$ & $1 \cdot 60$ & $0 \cdot 89$ \\
\hline C13 & 78 & 0.01470 & $29 \cdot 6$ & 20 & 480 & 190 & 1.05 & 1.07 & 1.02 & 1.89 & 1.09 \\
\hline \multicolumn{12}{|c|}{ Urban et al. (2013) } \\
\hline II-P25 & 218 & 0.00400 & $32 \cdot 5$ & 16 & 544 & 920 & $1 \cdot 12$ & 1.08 & $1 \cdot 51$ & $1 \cdot 71$ & $1 \cdot 53$ \\
\hline II-P30 & 268 & 0.00400 & $32 \cdot 5$ & 16 & 544 & 1280 & $1 \cdot 10$ & 1.03 & $1 \cdot 52$ & $1 \cdot 73$ & 1.46 \\
\hline II-P35 & 318 & 0.00400 & $32 \cdot 5$ & 16 & 580 & 2000 & $1 \cdot 29$ & $1 \cdot 17$ & $1 \cdot 79$ & $2 \cdot 05$ & $1 \cdot 84$ \\
\hline \multicolumn{12}{|c|}{ Oliveira et al. (2004) } \\
\hline L1b & 108 & 0.01080 & $59 \cdot 0$ & 16 & 479 & $322 \cdot 4$ & 1.02 & 0.99 & 0.96 & $1 \cdot 29$ & 1.08 \\
\hline L1c & 107 & 0.01090 & $59 \cdot 0$ & 16 & 479 & 318 & 1.02 & 0.99 & 0.95 & $1 \cdot 29$ & 1.08 \\
\hline $\mathrm{L} 2 \mathrm{~b}$ & 106 & 0.01100 & $58 \cdot 0$ & 16 & 479 & 361 & 1.09 & $1 \cdot 10$ & 0.97 & $1 \cdot 18$ & 1.04 \\
\hline L2C & 107 & 0.01090 & $57 \cdot 0$ & 16 & 479 & $330 \cdot 8$ & 0.99 & $1 \cdot 00$ & $0 \cdot 89$ & 1.08 & 0.90 \\
\hline $\mathrm{L} 3 \mathrm{~b}$ & 107 & 0.01090 & $60 \cdot 0$ & 16 & 479 & 400 & $1 \cdot 13$ & $1 \cdot 17$ & 0.94 & 1.05 & 0.97 \\
\hline $\mathrm{L} 3 \mathrm{C}$ & 106 & 0.01100 & $54 \cdot 0$ & 16 & 479 & $357 \cdot 6$ & 1.05 & 1.08 & $0 \cdot 88$ & 1.01 & 0.87 \\
\hline$L 4 b$ & 106 & 0.01100 & $54 \cdot 0$ & 16 & 479 & 395 & $1 \cdot 11$ & $1 \cdot 17$ & 0.88 & 0.95 & 0.86 \\
\hline L4c & 107 & 0.01090 & $56 \cdot 0$ & 16 & 479 & 404 & $1 \cdot 11$ & $1 \cdot 17$ & $0 \cdot 88$ & 0.94 & $0 \cdot 86$ \\
\hline $\mathrm{L} 5 \mathrm{~b}$ & 108 & 0.01080 & $67 \cdot 0$ & 16 & 479 & $426 \cdot 4$ & $1 \cdot 08$ & $1 \cdot 14$ & $0 \cdot 80$ & 0.78 & 0.73 \\
\hline $\mathrm{L} 5 \mathrm{C}$ & 109 & 0.01070 & $63 \cdot 0$ & 16 & 479 & $446 \cdot 4$ & $1 \cdot 13$ & $1 \cdot 20$ & $0 \cdot 85$ & 0.83 & $0 \cdot 80$ \\
\hline \multicolumn{12}{|c|}{ Al-Yousif and Regan (2003) } \\
\hline 2 & 80 & 0.00982 & $29 \cdot 0$ & 10 & 472 & 209 & $1 \cdot 12$ & $1 \cdot 22$ & 0.83 & 0.97 & 0.86 \\
\hline 4 & 80 & 0.00982 & $27 \cdot 5$ & 10 & 472 & 242 & $1 \cdot 21$ & $1 \cdot 34$ & 0.98 & $1 \cdot 15$ & $1 \cdot 13$ \\
\hline
\end{tabular}

Table A1. Continued 


\begin{tabular}{|c|c|c|c|c|c|c|c|c|c|c|c|}
\hline \multirow[b]{2}{*}{ Specimen } & \multirow[b]{2}{*}{$d: m m$} & \multirow[b]{2}{*}{$\rho$} & \multirow[b]{2}{*}{$f_{\mathrm{c}}: \mathrm{MPa}$} & \multirow[b]{2}{*}{$d_{g}: m m$} & \multirow[b]{2}{*}{$f_{\mathrm{y}}: \mathrm{MPa}$} & \multirow[b]{2}{*}{$V_{u, \text { test }}: k N$} & \multicolumn{5}{|c|}{$V_{\mathrm{R}, \text { cald }} / V_{\mathrm{u} \text {, test }}$} \\
\hline & & & & & & & Equation 13 & Equation 14 & Eurocode 2 & $\begin{array}{c}\mathrm{ACl} \\
318-14\end{array}$ & $\begin{array}{c}\text { MC2010 } \\
\text { (LoA2) }\end{array}$ \\
\hline \multicolumn{12}{|c|}{ Ghannoum (1998) } \\
\hline S1-U & 110 & 0.00960 & $37 \cdot 2$ & 20 & 445 & 301 & 0.93 & 0.98 & 0.86 & 1.01 & 0.85 \\
\hline S1-B & 110 & 0.01920 & $37 \cdot 2$ & 20 & 445 & 317 & 0.79 & 0.80 & 0.72 & 1.07 & 0.71 \\
\hline S2-U & 110 & 0.00960 & $57 \cdot 1$ & 20 & 445 & 363 & 1.01 & 1.06 & 0.90 & 0.99 & 0.91 \\
\hline S2-B & 110 & 0.01920 & $57 \cdot 1$ & 20 & 445 & 447 & 0.98 & 1.00 & 0.88 & $1 \cdot 22$ & 0.89 \\
\hline SE-B & 110 & 0.01920 & $67 \cdot 1$ & 10 & 445 & 485 & 1.02 & 1.04 & 0.90 & $1 \cdot 22$ & 1.02 \\
\hline \multicolumn{12}{|c|}{ McHarg (1997) } \\
\hline NSCU & 110 & 0.00960 & $30 \cdot 0$ & 20 & 434 & 306 & 1.00 & 1.05 & 0.94 & $1 \cdot 15$ & 0.98 \\
\hline NSCB & 110 & 0.01920 & $30 \cdot 0$ & 20 & 434 & 349 & 0.93 & 0.93 & 0.85 & $1 \cdot 31$ & 0.91 \\
\hline \multicolumn{12}{|c|}{ Kevin (2000) } \\
\hline P100 & 100 & 0.00980 & $39 \cdot 4$ & 20 & 488 & 330 & $1 \cdot 18$ & $1 \cdot 23$ & 1.09 & $1 \cdot 33$ & 0.91 \\
\hline P150 & 150 & 0.00900 & $39 \cdot 4$ & 20 & 465 & 583 & $1 \cdot 11$ & $1 \cdot 10$ & $1 \cdot 14$ & $1 \cdot 34$ & 0.95 \\
\hline P200 & 200 & 0.00830 & $39 \cdot 4$ & 20 & 465 & 904 & 1.09 & 1.04 & $1 \cdot 19$ & $1 \cdot 36$ & 1.02 \\
\hline P300 & 300 & 0.00760 & $39 \cdot 4$ & 20 & 468 & 1381 & 0.86 & $0 \cdot 77$ & 0.99 & $1 \cdot 11$ & 0.83 \\
\hline \multicolumn{12}{|c|}{ Base (fib, 2001) } \\
\hline $\mathrm{A} 1 / \mathrm{M} 1$ & 114 & 0.01100 & $15 \cdot 5$ & 16 & 255 & 322 & $1 \cdot 10$ & $1 \cdot 10$ & $1 \cdot 17$ & $1 \cdot 71$ & $1 \cdot 36$ \\
\hline $\mathrm{A} 1 / \mathrm{M} 2$ & 117 & 0.01500 & $14 \cdot 7$ & 16 & 282 & 346 & 1.08 & 1.05 & $1 \cdot 11$ & 1.83 & $1 \cdot 30$ \\
\hline $\mathrm{A} 1 / \mathrm{M} 3$ & 121 & 0.01900 & $13 \cdot 5$ & 16 & 282 & 307 & 0.86 & 0.81 & 0.90 & 1.61 & 1.04 \\
\hline $\mathrm{A} 1 / \mathrm{M} 4$ & 124 & 0.01000 & $13 \cdot 3$ & 16 & 432 & 259 & 0.82 & 0.77 & 0.91 & $1 \cdot 33$ & 0.91 \\
\hline A1/M5 & 117 & 0.01200 & $20 \cdot 0$ & 16 & 432 & 346 & 1.07 & 1.04 & 1.08 & 1.57 & $1 \cdot 14$ \\
\hline $\mathrm{A} 2 / \mathrm{M} 1$ & 124 & 0.01000 & $33 \cdot 6$ & 16 & 255 & 409 & 1.08 & $1 \cdot 11$ & 1.06 & $1 \cdot 32$ & $1 \cdot 10$ \\
\hline $\mathrm{A} 2 / \mathrm{M} 2$ & 117 & 0.01500 & $31 \cdot 2$ & 16 & 282 & 419 & $1 \cdot 11$ & $1 \cdot 12$ & 1.05 & $1 \cdot 52$ & $1 \cdot 12$ \\
\hline A2/M3 & 121 & 0.01900 & $30 \cdot 9$ & 16 & 282 & 430 & 1.00 & 0.99 & 0.95 & 1.49 & 1.01 \\
\hline $\mathrm{A} 2 / \mathrm{T} 1$ & 124 & 0.01000 & $37 \cdot 3$ & 16 & 432 & 419 & 1.06 & 1.07 & 1.04 & $1 \cdot 28$ & 1.01 \\
\hline $\mathrm{A} 2 / \mathrm{T} 2$ & 124 & 0.01700 & $39 \cdot 3$ & 16 & 432 & 439 & 0.94 & 0.93 & 0.90 & $1 \cdot 31$ & 0.87 \\
\hline $\mathrm{A} 3 / \mathrm{M} 1$ & 124 & 0.01000 & $17 \cdot 9$ & 16 & 255 & 247 & 0.74 & 0.75 & 0.79 & 1.09 & 0.75 \\
\hline $\mathrm{A} 3 / \mathrm{M} 2$ & 102 & 0.01700 & $18 \cdot 3$ & 16 & 282 & 336 & $1 \cdot 19$ & $1 \cdot 18$ & $1 \cdot 16$ & 1.91 & 1.41 \\
\hline $\mathrm{A} 3 / \mathrm{M} 3$ & 117 & 0.01900 & $25 \cdot 9$ & 16 & 282 & 298 & 0.77 & 0.76 & 0.73 & $1 \cdot 18$ & 0.74 \\
\hline $\mathrm{A} 3 / \mathrm{T} 1$ & 121 & 0.01000 & $19 \cdot 6$ & 16 & 432 & 328 & 1.00 & 0.98 & 1.05 & $1 \cdot 43$ & 1.06 \\
\hline $\mathrm{A} 3 / \mathrm{T} 2$ & 119 & 0.01200 & $15 \cdot 2$ & 16 & 432 & 298 & 0.95 & 0.90 & 1.00 & 1.51 & 1.05 \\
\hline $\mathrm{A} 4 / \mathrm{M} 1$ & 114 & 0.01100 & $36 \cdot 4$ & 16 & 255 & 259 & 0.76 & 0.78 & 0.71 & 0.90 & 0.63 \\
\hline $\mathrm{A} 4 / \mathrm{M} 2$ & 119 & 0.01500 & $27 \cdot 7$ & 16 & 282 & 341 & 0.90 & 0.91 & 0.87 & $1 \cdot 28$ & 0.87 \\
\hline A4/M3 & 117 & 0.01900 & $30 \cdot 6$ & 16 & 322 & 541 & $1 \cdot 32$ & $1 \cdot 31$ & $1 \cdot 26$ & 1.98 & 1.47 \\
\hline $\mathrm{A} 4 / \mathrm{T} 1$ & 114 & 0.01100 & $31 \cdot 2$ & 16 & 432 & 384 & $1 \cdot 13$ & $1 \cdot 15$ & $1 \cdot 10$ & $1 \cdot 44$ & $1 \cdot 13$ \\
\hline $\mathrm{A} 4 / \mathrm{T} 2$ & 117 & 0.01200 & $27 \cdot 8$ & 16 & 432 & 402 & $1 \cdot 14$ & $1 \cdot 14$ & $1 \cdot 13$ & $1 \cdot 54$ & $1 \cdot 17$ \\
\hline \multicolumn{12}{|c|}{ Hegger et al. (2009) } \\
\hline DF11 & 395 & 0.00870 & $21 \cdot 4$ & 16 & 552 & 2813 & $1 \cdot 37$ & $1 \cdot 14$ & $1 \cdot 51$ & 1.96 & $1 \cdot 40$ \\
\hline DF12 & 395 & 0.00870 & $21 \cdot 1$ & 16 & 552 & 2208 & 1.07 & 0.89 & $1 \cdot 19$ & 1.55 & 1.07 \\
\hline DF13 & 395 & 0.00870 & $21 \cdot 2$ & 16 & 552 & 1839 & 0.91 & 0.75 & 0.99 & $1 \cdot 29$ & 0.89 \\
\hline DF20 & 395 & 0.00870 & $35 \cdot 7$ & 16 & 552 & 3037 & $1 \cdot 24$ & 1.06 & $1 \cdot 38$ & 1.64 & $1 \cdot 18$ \\
\hline DF21 & 395 & 0.00870 & $36 \cdot 3$ & 16 & 552 & 2860 & $1 \cdot 16$ & 0.99 & $1 \cdot 29$ & 1.53 & $1 \cdot 12$ \\
\hline \multirow[t]{3}{*}{ DF22 } & 395 & 0.00870 & $36 \cdot 4$ & 16 & 552 & 2405 & 0.98 & 0.84 & 1.08 & $1 \cdot 28$ & 0.94 \\
\hline & & & & & & Average & 1.02 & 1.00 & 1.02 & 1.44 & 1.08 \\
\hline & & & & & & $\mathrm{CoV}$ & $0 \cdot 13$ & 0.14 & $0 \cdot 15$ & 0.25 & 0.21 \\
\hline
\end{tabular}

Table A1. Continued 


\section{REFERENCES}

ACl (American Concrete Institute) (2014) ACI 318-14: Building code requirements for structural concrete and commentary. ACI, Farmington Hills, MI, USA.

Al-Yousif AT and Regan PE (2003) Punching resistances of RC slabs supported by large and/or elongated columns. The Structural Engineer 81(5): 30-34.

Bazant ZP and Cao Z (1987) Size effect in punching shear failure of slabs. ACI Structural Journal 84(1): 44-53, http://dx.doi.org/10.14359/2785.

Bernaert M and Puech M (1966) Compte Rendu des Travaux du Groupe de Travail Poinconnement. Lausanne, Switzerland, Comité Européen du Béton, CEB bulletin 57.

Beutel R (2002) Durchstanzen Schubwehrter Flachdecken im Beriech von Innenstutzen. PhD dissertation, RWTH Aachen, Aachen, Germany.

Birkle G and Digler WH (2008) Influence of slab thickness on punching shear strength. ACI Structural Journal 105(2): 180-188, http://dx.doi.org/10.14359/19733.

Bompa DV and Oneț T (2011) Failure analysis of symmetric flat slab column connections. Proceedings of fib Symposium, Prague, Czech Republic.

Broms CE (1990) Punching of flat plates - a question of concrete properties in biaxial compression and size effect. ACI Structural Journal 87(3): 292-304, http://dx.doi.org/10. $14359 / 2624$.

Caldentey AP, Lavaselli PP, Peiretti HC and Fernandez FA (2013) Influence of stirrup detailing on punching shear strength of flat slabs. Engineering Structures 49(??): 855-865, http://dx. doi.org/10.1016/j.engstruct.2012.12.032.

CEN (European Committee for Standardization) (2004) EN 1992-1-1, Eurocode 2: Design of concrete structures, Part 1-1: General rules for buildings. CEN, Brussels, Belgium.

Chana PS (1987) Investigation of the mechanism of shear failure of reinforced concrete beams. Magazine of Concrete Research 56(6): 386-404, http://dx.doi.org/10.1680/macr. 1987.39.141.196.

Dei Poli S, Gambarova PG and Karakoc C (1987) Aggregate interlock role in $\mathrm{RC}$ thin-webbed beams in shear. ASCE Journal of Structural Engineering 113(1): 1-19, http://dx.doi.org/10.1061/(ASCE)0733-9445(1987) 113:1(1))

Dei Poli S, Di Prisco M and Gambarova P (1992) Shear response, deformations, and subgrade stiffness of a dowel bar embedded in concrete. ACI Structural Journal 89(6): 665-675, http://dx.doi.org/10.14359/9645.

DSS (Dassault Systèmes Simulia Corp.) (2010) Abaqus Analysis Users' Manual, Version 6.10. DSS, Providence, RI, USA.

Elstner RC and Hognestad E (1956) Shearing strength of reinforced concrete slabs. ACI Journal 53(7): 29-58, http:/ dx.doi.org/10.14359/11501.

fib (Federation Internationale du Beton) (2001) Punching of Structural Concrete Slabs. fib, Lausanne, Switzerland, fib bulletin 12 . fib (2012) Model Code 2010. fib, Lausanne, Switzerland, fib bulletins 65 and 66 .

Ghannoum CM (1998) Effect of High-Strength Concrete on the Performance of Slab-Column Specimens. MSc dissertation, McGill University, Montréal, Canada.

Gosav AV, Bompa DV and Kiss Z (2013) Failure analysis of interior flat-slab column connections with DHSR shear reinforcement. Proceedings of fib Symposium, Tel-Aviv, Israel.

Guandalini S, Burdet O and Muttoni A (2009) Punching tests of slabs with low reinforcement ratios. ACI Structural Journal 106(1): 87-95, http://dx.doi.org/10.14359/56287.

Guidotti R (2010) Essais de Poinconnement de Dalles en Beton Arme avec Colonnes Continues Fortement Sollicitees. PhD dissertation, Ibeton-EPFL, Lausanne, Switzerland.

Hallgren M (1996) Punching Shear Capacity of Reinforced High-Strength Slabs. PhD thesis, KTH Stockholm, Stockholm, Sweden, TRIT-BKN, Bulletin 23.

Hegger J, Ricker M and Sherif AG (2009) Punching strength of reinforced concrete footings. ACI Structural Journal 106(5): 706-719, http://dx.doi.org/10.14359/51663111.

Heinzmann D, Etter S, Villiger S and Jaeger T (2012) Punching tests on reinforced concrete slabs with and without shear reinforcement. ACI Structural Journal 109(6): 787-794, http://dx.doi.org/10.14359/51684122.

Inacio M, Ramos A, Lucio V and Faria D (2013) Punching of high strength concrete flat slabs. Proceedings of fib Symposium, Tel-Aviv, Israel.

Ince R, Yalcin E and Arslan A (2007) Size-dependent response of dowel action in RC members. Engineering Structures 29(6): 955-961, http://dx.doi.org/10.1016/j.engstruct.2006. 07.006.

Kevin KLL (2000) Influence of Size on Punching Shear Strength of Concrete Slabs. MSc dissertation, McGill University, Montréal, Canada.

Kinnunen S and Nylander H (1960) Punching of concrete slabs without shear reinforcement. Transactions of the Royal Institute of Technology 158(3): 1-112.

Krueger G (1999) Resistance au Poinconnement Excentre des Plancers Dalles. PhD dissertation, EPFL, Lausanne, Switzerland, No. 2064.

Ladner M (1998) Durchstanzversuch an Flachdeckenausshinitt. Hochschule Luzern Technik \& Architektur, Horw, Switzerland, Auftragsnummer 419-1.

Ladner M, Schaeidt W and Gus S (1977) Experimentelle Untersuchungen an Stahlbeton-Flachdecken. Eidgenössische Materiprüfungs- und Versuchsanstalt, Dübendorf, Switzerland, Bericht 205.

Marzouk H and Hussein H (1991) Punching shear analysis of reinforced high-strength concrete slabs. Canadian Journal of Civil Engineers 18(6): 954-963, http://dx.doi.org/10.1139/ 191-118.

McHarg PJ (1997) Effect of Fibre-Reinforced Concrete on the Performance of Slab-Column Specimens. MSc dissertation, McGill University, Montréal, Canada. 
Menetrey P (2002) Synthesis of punching failure in reinforced concrete. Cement \& Concrete Composites 24(6): 497-507, http://dx.doi.org/10.1016/S0958-9465(01)00066-X.

Moe J (1961) Shearing Strength of Reinforced Concrete Slabs and Footings Under Concentrated Loads. Portland Cement Association, Skokie, IL, ISA, Bulletin D47.

Mongi G (1990) A Critical Review of The Symmetric Punching Shear of Reinforced Concrete Flat Slabs. MASc dissertation, University of Ottawa, Ottawa, Canada.

Moreno CL and Sarment AM (2013) Punching shear analysis of slab-column connections. Engineering Computations: International Journal for Computer-Aided Engineering and Software 30(6): 802-814, http://dx.doi.org/10.1108/EC-Jun2012-0122.

Muttoni A (2008) Punching shear strength of reinforced concrete slabs without transverse reinforcement. ACI Structural Journal 105(4): 440-450, http://dx.doi.org/10. 14359/19858.

Muttoni A and Fernandez Ruiz M (2012) The levels-ofapproximation approach in MC2010: application to punching shear provisions. Structural Concrete 13(1): 32-41, http://dx.doi.org/10.1002/suco.201100032.

Nielsen MP (1999) Limit Analysis and Concrete Plasticity, 2nd edn). CRC Press, Boca Raton, FL, USA, pp. 22-31.

Oliveira DRC, Regan PE and Melo GSSA (2004) Punching resistance of RC slabs with rectangular columns. Magazine of Concrete Research 56(3): 123-138, http://dx.doi.org/10. 1680/macr.2004.56.3.123.

Ottosen NS (1980) Nonlinear Finite Element Analysis of Concrete Structures. Risø National Laboratory, Roskilde, Denmark.

Paulay T and Loeber PJ (1974) Shear Transfer By Aggregate Interlock. ACI, Farmington Hills, MI, USA, ACI Special Publication 42, pp. 1-16, http://dx.doi.org/10.14359/17277.

Pralong J (1982) Poinçonnement Symétrique des Planchersdalles. PhD dissertation, IBK, ETHZ, Zurich, Switzerland, http://dx.doi.org/10.3929/ethz-a-000262972.

Ramadane KE (1996) Punching shear of high performance concrete slabs. Proceedings of the Fourth Symposium on the Utilisation of High Strength/High Performance Concrete. Laboratoire Central des Ponts et Chaussées, Paris, France, Vol. 3, pp. 1015-1026.
Regan PE (1986) Symmetric punching of reinforced concrete slabs. Magazine of Concrete Research 38(136): 115-128, http://dx.doi.org/10.1680/macr.1986.38.136.115.

Regan PE and Braestrup MW (1985) Punching Shear in Reinforced Concrete. Comité Européen du Béton, CEB Lausanne, Switzerland, Bulletin D'Information 168.

Rizk E, Marzouk $\mathrm{H}$ and Hussein A (2011) Punching shear of thick plates with and without shear reinforcement. $A C I$ Structural Journal 108(5): 581-591, http://dx.doi.org/ $10.14359 / 51683215$.

Sagaseta J, Muttoni A, Fernandez Ruiz M and Tassinari L (2011) Non-axis-symmetrical punching shear around internal columns of RC slabs without transverse reinforcement. Magazine of Concrete Research 63(6): 441-457, http://dx.doi.org/10.1680/macr.10.00098.

Schaefers U (1984) Konstruction, Bemsessung und Sicherheit gegen Durchstanzen von balekenlosen Stahlbetondecken im bereich der Innenstutezen, DafStb heft 357. Beuth-Verlag, Berlin, Germany.

Swamy R and Ali S (1982) Punching shear behaviour of reinforced slab-column connections made with steel fibre concrete. ACI Journal 79(5): 392-406, http://dx.doi.org/ $10.14359 / 10917$.

Taylor HPJ (1970) Further Tests to Determine Shear Stresses in Reinforced Concrete Beams. Cement and Concrete Association, London, UK, Technical report TRA 438.

Tomaszewicz A (1993) High Strength Concrete, SP2 - Plates and Shells, Report 2.3 Punching Shear Capacity of Reinforced Concrete Slabs. SINTEF Structures and Concrete, Trondheim, Norway, Report STF70 A93082.

Urban T, Gołdyn M, Krakowski J and Krawczyk $Ł$ (2013) Experimental investigation of punching behaviour of thick reinforced concrete slabs. Archives of Civil Engineering LIX(2): 157-174, http://dx.doi.org/10.2478/ ace-2013-0008.

Walraven JC and Reinhardt HW (1981) Theory and experiments on the mechanical behaviour of cracks in plain and reinforced concrete subjected to shear loading. Heron 26(1a): 5-68.

Wörle P (2014) Enhanced shear punching capacity by the use of post installed concrete screws. Engineering Structures 60(1): 41-51, http://dx.doi.org/10.1016/j.engstruct.2013. 12.015 .

\section{WHAT DO YOU THINK?}

To discuss this paper, please submit up to 500 words to the editor at journals@ice.org.uk. Your contribution will be forwarded to the author(s) for a reply and, if considered appropriate by the editorial panel, will be published as a discussion in a future issue of the journal. 